University of Tennessee Health Science Center

UTHSC Digital Commons

\title{
Pronthocyanidin-Rich Cranberry-FractionInduced Alteration of Periodontal Pathogen Lipopolysaccharide Functions
}

Vreiti Sangha

University of Tennessee Health Science Center

Follow this and additional works at: https://dc.uthsc.edu/dissertations

Part of the Periodontics and Periodontology Commons

\section{Recommended Citation}

Sangha, Vreiti , "Pronthocyanidin-Rich Cranberry-FractionInduced Alteration of Periodontal Pathogen Lipopolysaccharide Functions" (2012). Theses and Dissertations (ETD). Paper 221. http://dx.doi.org/ 10.21007/etd.cghs.2012.0276.

This Thesis is brought to you for free and open access by the College of Graduate Health Sciences at UTHSC Digital Commons. It has been accepted for inclusion in Theses and Dissertations (ETD) by an authorized administrator of UTHSC Digital Commons. For more information, please contact jwelch30@uthsc.edu. 


\title{
Pronthocyanidin-Rich Cranberry-FractionInduced Alteration of Periodontal Pathogen Lipopolysaccharide Functions
}

\begin{abstract}
The cranberry (species: Vaccinium macrocarpon, family: Ericaceae) is a polyphenolicrich berry fruit native to North America and exhibits numerous beneficial properties for human health, such as inhibition of human cancer cell line proliferation and prevention of urinary tract colonization by bacterial pathogens. The proanthocyanidin rich cranberry fraction has long been speculated to possess the capacity to reduce the production of inflammatory mediators by LPSstimulated macrophages and gingival fibroblasts and to inhibit host extracellular matrix destructive enzyme production and activity.
\end{abstract}

The purpose of this investigation was to examine the effect of cranberry non dialyzable material (NDM), which was shown to be rich in proanthocyanidins; this has a suppressive effect on production of inflammatory cytokines mediated by LPS which are known to play a major destructive role in periodontal disease. In addition to the cytokines, stimulation of superoxide ions by the monocytes also contributes to the severity of periodontal disease. In this study we chose to investigate the effect of NDM on LPSmediated stimulation of the cultured monocytic cells (THP-1) to secrete the two cytokines; IL-1 $\beta$ and TNF$\alpha$, and also on superoxide release. We chose to study the effect of NDM on biological functions of isolated LPS from periodontal pathogens. LPS was isolated from P. gingivalis, T. denticola and $F$. nucleatum.

Secretion of the two cytokines by the cultured monocytes was found to be dosedependent upon the concentration of LPS. Secretion of TNF- $\alpha$ varied from $110 \pm 28$ to $610 \pm 42$ picograms $/ \mathrm{ml}(\mathrm{pg} / \mathrm{ml})$ when stimulated cells with 1.0 and $20 \mathrm{ng} / \mathrm{ml}$ of LPS. Similarly, IL-1 $\beta$ secretion varied from $49 \pm 6$ to $196 \pm 16 \mathrm{pg} /$ $\mathrm{ml}$. The LPS of both T. denticola and F. nucleatum also exhibited similar phenomenon. In the presence of $\operatorname{NDM}(20 \mu \mathrm{g} / \mathrm{ml})$, the cells secreted $80-90 \%$ less of the two cytokines when stimulated with LPS. LPS isolated from the same three oral pathogens grown in the presence of NDM $(10-20 \mu \mathrm{g} / \mathrm{ml})$ also failed to stimulate the monocytes compared to the LPS isolated from bacteria grown in culture media alone. Interestingly, when the THP-1 cells were first incubated with NDM, the cranberry components also caused a significant decrease in the secretion of cytokines. The results of the study strongly indicate the suppressive effect of NDM on LPS-mediated secretion of cytokines by the monocytic cells. It may be possible that the NDM may be interfering with LPS interaction with LPS binding protein and the CD-14, a known receptor on the monocytes which triggers the secretion of cytokine molecules.

The LPS of pathogenic bacteria induces the monocytic cells to secrete superoxide ions; a mechanism which aids in tissue destruction. Our results showed that the LPS isolated from all three pathogens stimulated cells to secrete superoxide ions several folds higher (65 to $89 \%$ ) than the control cells which were not exposed to LPS. Cultured monocytic cells when incubated with LPS along with NDM secreted significantly lesser superoxide ions (60-70\% reduction). The results of the study clearly demonstrated that the cranberry NDM alters the biological functions of bacterial LPS. The NDM inhibited the secretion of cytokines and also superoxide ions by the cultured monocytes in response to LPS.

Therapeutic agents that modulate host inflammatory mediators have shown promise for managing adult periodontitis and may be highly useful for individuals with a substantially increased risk for periodontitis. In addition to the previously recognized inhibitory effect of the cranberry non-dialyzable material fraction on the aggregation of oral bacteria and dental biofilm formation we showed that this fraction was a potent inhibitor of the pro-inflammatory cytokines and superoxide ions induced by LPS of periodontopathogens. This provides promising perspectives for the development of novel hostmodulating therapies for adjunctive treatments of periodontitis or other inflammatory diseases by use of the high molecular weight constituents from cranberries. 


\section{Document Type}

Thesis

\section{Degree Name}

Master of Dental Science (MDS)

\section{Program}

Periodontology

\section{Research Advisor}

Jegdish P. Babu, M.S., Ph.D.

\section{Keywords}

Cranberry, NDM, Periodontal pathogens, Proanthocyanidin

\section{Subject Categories}

Dentistry | Medicine and Health Sciences | Periodontics and Periodontology 

FUNCTIONS

\author{
A Thesis \\ Presented for \\ The Graduate Studies Council \\ The University of Tennessee \\ Health Science Center
}

\author{
In Partial Fulfillment \\ Of the Requirements for the Degree \\ Master of Dental Science \\ From The University of Tennessee
}

By

Vreiti Sangha, D.D.S.

May 2012 
Copyright (C) 2012 by Vreiti Sangha. All rights reserved. 


\section{DEDICATION}

I would like to dedicate this thesis to my husband, Peter Sangha for his support and patience through this whole process and to my parents for their faith in me. 


\section{ACKNOWLEDGEMENTS}

I would like to thank Dr. Jegdish Babu for being my research mentor. I can't thank him enough for his support, patience, understanding, and wonderful sense of humor throughout this research project. Dr. Babu has been an exemplary mentor and I have been fortunate enough to be under his guidance.

I would like to thank my Committee members Drs. Anastasios Karydis, Sidney H. Stein, and David A. Tipton for their valuable suggestions.

I would like to thank The University of Tennessee Health Science Center, College of Dentistry Alumni Endowment Fund and Tennessee Dental Association Fund for their financial support of this project. 


\begin{abstract}
The cranberry (species: Vaccinium macrocarpon, family: Ericaceae) is a polyphenolic-rich berry fruit native to North America and exhibits numerous beneficial properties for human health, such as inhibition of human cancer cell line proliferation and prevention of urinary tract colonization by bacterial pathogens. The proanthocyanidin rich cranberry fraction has long been speculated to possess the capacity to reduce the production of inflammatory mediators by LPS-stimulated macrophages and gingival fibroblasts and to inhibit host extracellular matrix destructive enzyme production and activity.
\end{abstract}

The purpose of this investigation was to examine the effect of cranberry non dialyzable material (NDM), which was shown to be rich in proanthocyanidins; this has a suppressive effect on production of inflammatory cytokines mediated by LPS which are known to play a major destructive role in periodontal disease. In addition to the cytokines, stimulation of superoxide ions by the monocytes also contributes to the severity of periodontal disease. In this study we chose to investigate the effect of NDM on LPS-mediated stimulation of the cultured monocytic cells (THP-1) to secrete the two cytokines; IL- $1 \beta$ and TNF- $\alpha$, and also on superoxide release. We chose to study the effect of NDM on biological functions of isolated LPS from periodontal pathogens. LPS was isolated from $P$. gingivalis, $T$. denticola and $F$. nucleatum.

Secretion of the two cytokines by the cultured monocytes was found to be dosedependent upon the concentration of LPS. Secretion of TNF- $\alpha$ varied from $110 \pm 28$ to $610 \pm 42$ picograms $/ \mathrm{ml}(\mathrm{pg} / \mathrm{ml})$ when stimulated cells with 1.0 and $20 \mathrm{ng} / \mathrm{ml}$ of LPS. Similarly, IL-1 $\beta$ secretion varied from $49 \pm 6$ to $196 \pm 16 \mathrm{pg} / \mathrm{ml}$. The LPS of both $T$. denticola and $F$. nucleatum also exhibited similar phenomenon. In the presence of NDM $(20 \mu \mathrm{g} / \mathrm{ml})$, the cells secreted $80-90 \%$ less of the two cytokines when stimulated with LPS. LPS isolated from the same three oral pathogens grown in the presence of NDM $(10-20 \mu \mathrm{g} / \mathrm{ml})$ also failed to stimulate the monocytes compared to the LPS isolated from bacteria grown in culture media alone. Interestingly, when the THP-1 cells were first incubated with NDM, the cranberry components also caused a significant decrease in the secretion of cytokines. The results of the study strongly indicate the suppressive effect of NDM on LPS-mediated secretion of cytokines by the monocytic cells. It may be possible that the NDM may be interfering with LPS interaction with LPS binding protein and the CD-14, a known receptor on the monocytes which triggers the secretion of cytokine molecules.

The LPS of pathogenic bacteria induces the monocytic cells to secrete superoxide ions; a mechanism which aids in tissue destruction. Our results showed that the LPS isolated from all three pathogens stimulated cells to secrete superoxide ions several folds higher (65 to 89\%) than the control cells which were not exposed to LPS. Cultured monocytic cells when incubated with LPS along with NDM secreted significantly lesser superoxide ions (60-70\% reduction). The results of the study clearly demonstrated that the cranberry NDM alters the biological functions of bacterial LPS. The NDM inhibited 
the secretion of cytokines and also superoxide ions by the cultured monocytes in response to LPS.

Therapeutic agents that modulate host inflammatory mediators have shown promise for managing adult periodontitis and may be highly useful for individuals with a substantially increased risk for periodontitis. In addition to the previously recognized inhibitory effect of the cranberry non-dialyzable material fraction on the aggregation of oral bacteria and dental biofilm formation we showed that this fraction was a potent inhibitor of the pro-inflammatory cytokines and superoxide ions induced by LPS of periodontopathogens. This provides promising perspectives for the development of novel host-modulating therapies for adjunctive treatments of periodontitis or other inflammatory diseases by use of the high molecular weight constituents from cranberries. 


\section{TABLE OF CONTENTS}

CHAPTER 1. INTRODUCTION AND LITERATURE REVIEW ..........................1

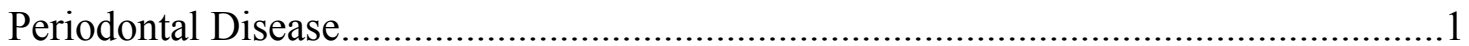

Cytokine Secretion Meditated by LPS..................................................................2

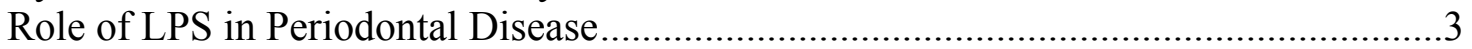

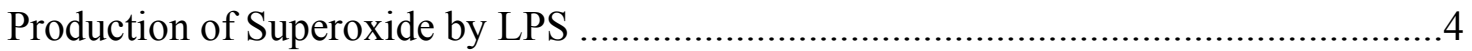

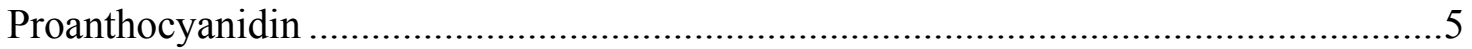

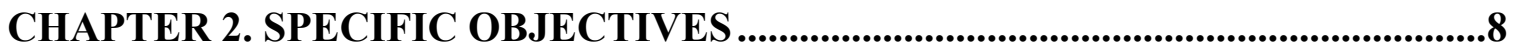

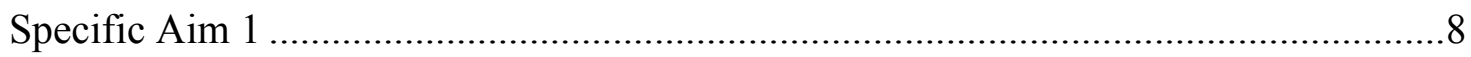

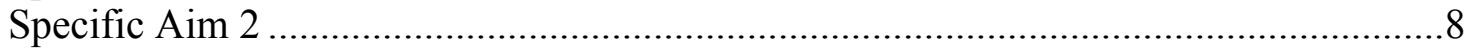

CHAPTER 3. MATERIALS AND METHODOLOGY .............................................10

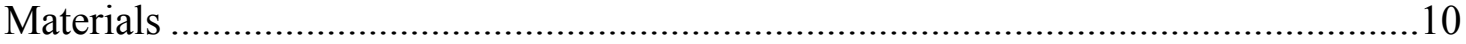

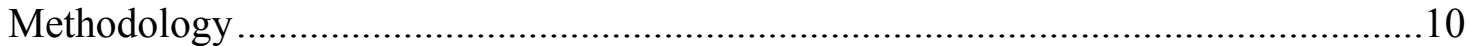

Cranberry NDM Preparation........................................................................ 10

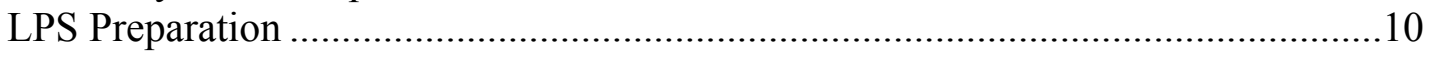

Limulus Amoebocyte Lysate (LAL) Assays ........................................................ 11

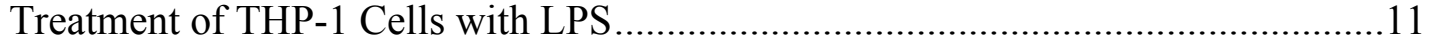

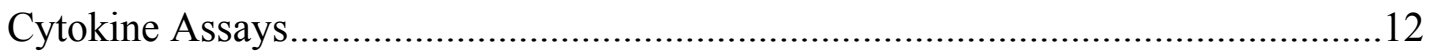

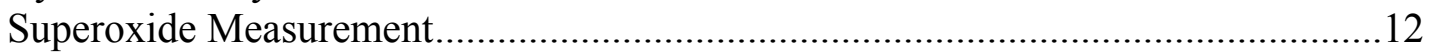

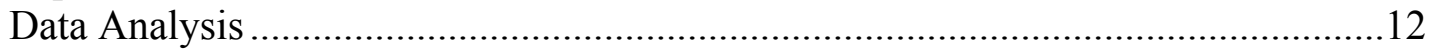

CHAPTER 4. RESULTS......................................................................................................13

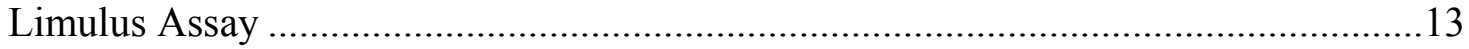

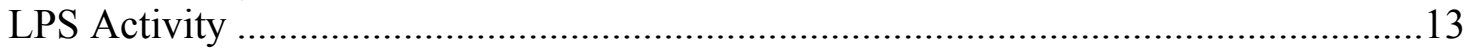

Secretion of TNF- $\alpha$ and IL-1 $\beta$ by THP-1 Cells Stimulated with LPS of

$P$. gingivalis, $T$. denticola and $F$. nucleatum That Had Been Grown in the Presence

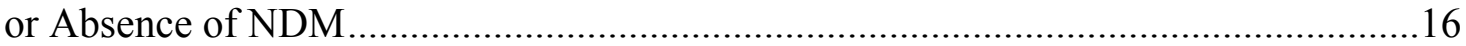

TNF- $\alpha$ and IL-1 $\beta$ Secretion by the THP- 1 Cells When Both Bacterial LPS and

NDM Were Added Simultaneously ...................................................................21

TNF- $\alpha$ and IL-1 $\beta$ Secretion by THP-1 Cells When They Were Pre-Incubated with

NDM for 60 Minutes and Then Stimulated with Bacterial LPS.................................26

Effect of Cranberry NDM on LPS-Induced Superoxide Production by THP-1 Cells...26

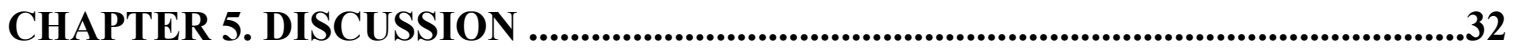

Cytokine Secretion by THP-1 Cells in Response to Isolated LPS of Periodontal

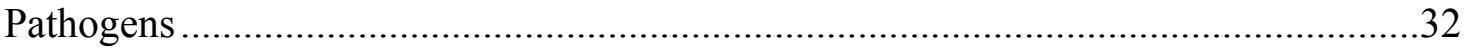

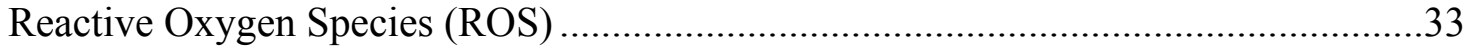

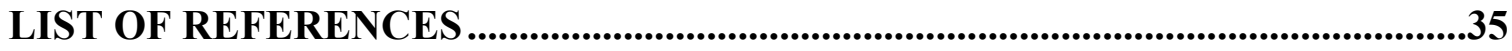

VITA 


\section{LIST OF FIGURES}

Figure 4-1. Endotoxin activity of LPS preparations from E. coli and oral pathogens at $10 \mathrm{ng} / \mathrm{ml}$.

Figure 4-2. TNF- $\alpha$ and IL-1 $\beta$ secretion by THP-1 cells in response to $P$. gingivalis LPS.

Figure 4-3. TNF- $\alpha$ and IL-1 $\beta$ secretion by THP-1 cells in response to $T$. denticola LPS.

Figure 4-4. TNF- $\alpha$ and IL-1 $\beta$ secretion by THP-1 cells in response to $F$. nucleatum LPS.

Figure 4-5. Secretion of TNF- $\alpha$ and IL-1 $\beta$ by THP-1 cells stimulated with LPS of $P$. gingivalis grown in presence or absence of NDM.

Figure 4-6. Secretion of TNF- $\alpha$ and IL-1 $\beta$ by THP-1 cells stimulated with LPS of $T$. denticola grown in presence or absence of NDM.

Figure 4-7. Secretion of TNF- $\alpha$ and IL-1 $\beta$ by THP-1 cells stimulated with LPS of $F$. nucleatum grown in presence or absence of NDM.

Figure 4-8. Concentration of TNF- $\alpha$ and IL-1 $\beta$ secreted by THP-1 cells that were stimulated with $P$. gingivalis LPS and NDM simultaneously.....

Figure 4-9. Concentration of TNF- $\alpha$ and IL-1 $\beta$ secreted by THP-1 cells that were stimulated simultaneously with $T$. denticola LPS and NDM.

Figure 4-10. Concentration of TNF- $\alpha$ and IL-1 $\beta$ secreted by THP-1 cells that were stimulated simultaneously with $F$. nucleatum LPS and NDM...

Figure 4-11. Concentration of TNF- $\alpha$ and IL-1 $\beta$ secreted by THP- 1 cells that were pre-incubated for 60 minutes with 10 and $20 \mu \mathrm{g} / \mathrm{ml}$ of NDM and then stimulated with $P$. gingivalis LPS.

Figure 4-12. Concentration of TNF- $\alpha$ and IL-1 $\beta$ secreted by THP-1 cells that were pre-incubated for 60 minutes with 10 and $20 \mu \mathrm{g} / \mathrm{ml}$ of NDM and then stimulated with $T$. denticola LPS.

Figure 4-13. Concentration of TNF- $\alpha$ and IL-1 $\beta$ secreted by THP-1 cells that were pre-incubated for 60 minutes with 10 and $20 \mu \mathrm{g} / \mathrm{ml}$ of NDM and then stimulated with $F$. nucleatum LPS.

Figure 4-14. Effect of cranberry NDM on LPS-induced superoxide production by THP-1 cells. 


\section{LIST OF ABBREVIATIONS}

\begin{tabular}{|c|c|}
\hline$\mu \mathrm{g} / \mathrm{ml}$ & Microgram per Milliliter \\
\hline$A a$ & $\begin{array}{l}\text { Aggregatibacter actinomycetemcomitans, } A \text {. } \\
\text { actinomycetemcomitans }\end{array}$ \\
\hline ATCC & American Type Culture Collection \\
\hline $\mathrm{CP}$ & Chronic Periodontitis \\
\hline E. $\operatorname{coli}(E c)$ & Escherichia coli \\
\hline ELISA & Enzyme-Linked Immunosorbent Assay \\
\hline F. nucleatum (Fn) & Fusobacterium nucleatum \\
\hline FTF & Fructosyltransferase \\
\hline GCF & Gingival Crevicular Fluid \\
\hline GPX & Glutathione Peroxidase \\
\hline GSH & Glutathione \\
\hline GTF & Glucosyltransferase \\
\hline $\mathrm{H}_{2} \mathrm{O}_{2}$ & Hydrogen Peroxide \\
\hline IFN- $\gamma$ & Interferon Gamma \\
\hline IL-1 & Interleukin-1 \\
\hline IL-1 $\alpha$ & Interleukin-1 Alpha \\
\hline IL-1 $\beta$ & Interleukin-1 Beta \\
\hline IL-1 ra & IL-1 Receptor Antagonist \\
\hline IL-6 & Interleukin-6 \\
\hline IL-8 & Interleukin-8 \\
\hline LBP & Lipopolysaccharide Binding Protein \\
\hline
\end{tabular}




\begin{tabular}{|c|c|}
\hline LPS & Lipopolysaccharide \\
\hline MMP & Matrix Metalloproteinase \\
\hline MMP-1 & Matrix Metalloproteinase-1 \\
\hline MMP-9 & Matrix Metalloproteinase-9 \\
\hline NADPH & Nicotinamide Adenine Dinucleotide Phosphate \\
\hline NDM & Non Dialyzable Material \\
\hline NF- $\kappa B$ & Nuclear Factor-Kappa B \\
\hline $\mathrm{O}_{2}^{-}$ & Superoxide Ions \\
\hline $\mathrm{OH}^{-}$ & Hydroxyl Radical \\
\hline$P$. gingivalis $(P g)$ & Porphyromonas gingivalis \\
\hline P. intermedia & Provetella intermedia \\
\hline P. micros & Peptostreptococcus micros \\
\hline P. nigrescens & Provetella nigrescens \\
\hline PAC & Proanthocyanidin \\
\hline $\mathrm{PGE}_{2}$ & Prostaglandin $E_{2}$ \\
\hline $\mathrm{pg} / \mathrm{ml}$ & Picograms per Milliliter \\
\hline PMN & Polymorphonuclear Leukocyte \\
\hline Prx & Peroxiredoxins \\
\hline ROS & Reactive Oxygen Species \\
\hline S. constellatu & Streptococcus constellatu \\
\hline S. sorbrinus & Streptococcus sobrinus \\
\hline SOD & Superoxide Dismutase \\
\hline T. denticola $(T d)$ & Treponema denticola \\
\hline
\end{tabular}


THB-HK

THP-1

TLR

TLR-2

TLR-4

TNF

TNF- $\alpha$
Todd Hewitt Broth Supplemented with Heme and Vit K

Human Acute Monocytic Leukemia Cell Line

Toll-Like Receptor

Toll-Like Receptor 2

Toll-Like Receptor 4

Tumor Necrosis Factor

Tumor Necrosis Factor-Alpha 


\section{CHAPTER 1. INTRODUCTION AND LITERATURE REVIEW}

\section{Periodontal Disease}

Periodontitis is a chronic inflammatory bacteriogenic infection leading to the destruction of the attachment apparatus including alveolar bone and connective tissue. Gingivitis and periodontitis are among the most common human infections. It has been estimated that in the United States, at least $35 \%$ of adults aged 30 years and older have periodontitis of which $22 \%$ have a mild form, and $13 \%$ have a moderate or severe form [1]. According to a report by the World Health Organization, Periodontitis leading to tooth loss was found in 5-15\% of most populations worldwide [2].

Periodontal disease is a chronic microbial and inflammatory process characterized by the presence of sulcular pathogenic bacteria, impaired host immune response and destruction of the connective tissue attachment. Periodontitis is associated with a complex microflora, in which Gram-negative anaerobic rods and spirochetes dominate [3]. More than 500 different bacterial species are able to colonize the oral biofilm and up to 150 different species of bacteria are possible in any individual's sub-gingival plaque. It is known to be caused by a specific group of gram-negative anaerobic bacteria, including Porphyromonas gingivalis, Treponema denticola, and Tannerella forsythia [4]. The flora associated with teeth from patients without gingival disease contained a predominantly coccoid flora with most cells exhibiting cell wall characteristics compatible with those of gram-positive microorganisms. On the other hand, the presence of an increased proportion of filamentous organisms in the supragingival microbial deposits appears to be associated with clinically detectable inflammation of the gingival tissues. This was particularly evident in the gingivitis and periodontitis samples, in which the supragingival deposits appeared to be composed predominantly of filamentous microorganisms arranged perpendicularly to the tooth surface and tightly held together by a distinct interbacterial matrix [5].

Periodontitis may involve both the direct cytotoxic and proteolytic effects of oral microorganisms and the indirect pathologic consequences of the host immune response to these microorganisms. The red complex, which includes Porphyromonas gingivalis, Tannerella forsythia (formerly Bacteroides forsythus), and Treponema denticola, is strongly related to clinical measures of periodontitis, particularly pocket depth and bleeding on probing [5]. These three anaerobic gram-negative bacterial species produce a broad array of virulence factors that allow them to colonize sub-gingival sites, resist host defenses, and cause tissue destruction. $P$. gingivalis has been implicated as a principal anaerobic gram-negative bacterium not only in adult periodontitis but also in rapidly progressive periodontitis. Indeed, the presence of $P$. gingivalis in sub-gingival plaque correlates with disease severity, as assessed by attachment loss, periodontal pocket depth, and bleeding upon probing. It is interesting to note that sites harboring $P$. gingivalis alone or in combination with the other two species exhibited the deepest mean pocket depths. The red complex bacteria are also strongly associated with bleeding on probing. A wide variety of virulence factors, including lipopolysaccharide (LPS), 
fimbriae, hemagglutinin, and hemolysins have contributed to the pathogenicity of $P$. gingivalis. The orange complex included $F$. nucleatum subspecies. $P$. intermedia, P. nigrescens, $P$. micros, S. constellatus and three of the Campylobacter species. It is readily apparent that members of the red complex are rarely found in the absence of members of the orange complex. With increasing colonization by the orange complex, more sites are colonized by increasing numbers of the red complex. All species in the orange complex show a significant association with increasing pocket depth [6] F. nucleatum is an anaerobe; with a high capacity to adapt to and reduce an oxygenated environment. It is commonly isolated from human sub-gingival plaques associated with both healthy and periodontally diseased sites.

\section{Cytokine Secretion Meditated by LPS}

Cytokines play an important role in a number of different physiologic processes but also induce pathology if expressed inappropriately. The colonization of multiple bacterial species on the tooth surface leads to gingival inflammation and in some cases activates the destruction of connective tissue attachment and alveolar bone. Components of the microbial dental plaque have the capacity to activate the local host response by inducing the initial infiltrate of inflammatory cells including lymphocytes, macrophages, and polymorphonuclear leukocytes [7]. It has been well established that under the stimulation of bacterial products, that monocytes/macrophages, lymphocytes, and local resident cells such as fibroblasts and vascular endothelial cells synthesize a broad spectrum of cytokines. These cytokines have important pro-inflammatory effects and are related to periodontal tissue destruction that involves the stimulation of bone resorption and induction of tissue-degrading proteinases [8]. These cytokines act to up-regulate the adhesion molecule on leukocytes and endothelial cells, which is a necessary step for leukocytes to leave the vascular system and infiltrate the surrounding tissue. The induction of primary mediators such as interleukin-1 (IL-1) or tumor necrosis factor (TNF) stimulates the production of secondary mediators, including chemokines, which act as chemotactic cytokines and cyclooxygenases that produce prostaglandins. This leads to amplification of the inflammatory response, the induction of enzymes that degrade connective tissue, and osteoclastic bone resorption.

IL-1 is a pro-inflammatory cytokine that has large array of biological activites and directly regulates several genes expressed during inflammation. There are two principal forms of interleukin -1 that have agonist activity, IL-1 $\alpha$ and IL- $1 \beta$, with a third ligand, IL-1 receptor antagonist (IL-1ra) that functions as a competitive inhibitor. IL-1 $\alpha$ and $\beta$ typically have similar activities. There are several studies that implicate IL-1 in the pathogenesis of periodontal disease. TNF refers to two associated proteins, TNF- $\alpha$ and $-\beta$. Experimental evidence indicates that TNF plays a role in resistance to microbial pathogens.

IL-1 and TNF are produced by monocytes/macrophages, polymorphonuclear leukocytes, fibroblasts, epithelial cells, endothelial cells, and osteoblasts. They have been shown to contribute to several events that are essential for initiation of an inflammatory 
response and ultimately leading to tissue destruction. They can induce up-regulation of adhesion molecules on leukocytes and endothelial cells and stimulate the production of chemokines, which are needed to recruit circulating leukocytes. IL-1 and TNF also induce expression of other mediators that amplify or sustain the inflammatory response such as prostaglandins, and the production of lytic enzymes such as metalloproteinases which can also enhance bacterial killing and phagocytic activity. It has been shown that IL-1 and TNF are synergistic in their capacity to enhance bone resorption. Although the periodontium has a high capacity for repair following injury, in some situations, cytokines may limit repair by inducing apoptosis of matrix-producing cells.

The production of cytokines within the gingival tissue leads to inflammatory cascade in this area. Once a "critical" level of pro-inflammatory cytokine production is reached, a physiologic response becomes a pathologic response. There are two critical factors for disease progression: 1) the degree of inflammation must be sufficient to result in a net increase in proteolytic enzyme activity and osteoclast formation, and 2) the position of the "inflammatory front" must progress further into the connective tissue so that it involves significant aspects of connective tissue attachment to teeth and be sufficiently close to alveolar bone [9].

\section{Role of LPS in Periodontal Disease}

LPS, or endotoxin, is the major component of the outer surface of Gram-negative bacteria. LPS is a potent activator of cells of the immune and inflammatory systems, including macrophages, monocytes, and endothelial cells, and contributes to systemic changes known as septic shock. Each LPS molecule has three regions: oligosaccharide, core, and lipid A. Oligosaccharide is exposed on the cell surface, and lipid A anchors LPS in the outer membrane. It is a structure consisting of four covalently linked segments, a surface carbohydrate polymer (O-specific chain), a core oligosaccharide featuring an outer and inner region, and an acylated glycolipid (termed lipid A). The Ospecific chain shows the most diversity, and is the basis for serological specificity, while lipid A, which anchors the LPS molecule in the gram-negative outer membrane, is the most conserved biochemical structure across different bacterial species. There is unequivocal acceptance that the lipid A moiety is the innate immune stimulating or"endotoxic" component of LPS.

LPS acts by initiating a cascade of host-mediated responses. Initially monocytes and macrophages are stimulated, and then neutrophils and platelets congregate in microcapillaries, causing vascular injury. Inflammatory cells release a range of endogenous mediators, including arachidonic acid metabolites, platelet-activating factor, cytokines such as IL-1, IL-6 and tumor necrosis factor-alpha (TNF- $\alpha$ ), nitric oxide, toxic $\mathrm{O}_{2}$ metabolites, vasoactive amines, proteases, along with products of the complement and coagulation cascades. LPS binds to specific receptors in order to elicit the release of cytokines and other inflammatory mediators. Several membrane-bound and soluble proteins have been shown to bind LPS; the most important appear to be CD14 and LPSbinding protein (LBP). Toll-like receptor (TLR) family are a group of transmembrane 
receptors that are fundamental in signaling innate immune responses to conserved microbial structures, and they are also involved in the recognition of some endogenous ligands. TLR4 is instrumental in signaling LPS from many Gram-negative bacteria and TLR2 is involved in the recognition of some unusual LPS [10]. TLR4 is the major signal transducer for most types of LPS, while TLR2 was suggested to be a signal transducer for other bacterial components such as peptidoglycans and lipoproteins. However, $P$. gingivalis LPS has been shown to activate cells through either TLR4 $[11,12]$ or TLR2 [13].

In the early stage of infection, epithelial cells (which are the first line of immune defense) respond strongly to $P$. gingivalis LPS by producing IL- 6 , INF- $\gamma$, or TNF- $\alpha$, leading to local tissue destruction. In the later stages of infection, bacteria and their virulence factors might move into the bloodstream through degraded gingival tissues and activate endothelial cells to express pro-inflammatory mediators such as IL-8 and MCP-1 that are involved in leukocyte chemotaxis and migration across the endothelium, as well as growth and differentiation factors, cell-adhesion molecules, and Toll-like receptors [14]. The continuous high secretion of various cytokines including IL-1, IL-6, IL-8, and TNF $\alpha$ by host cells following stimulation by periodontopathogens modulates periodontal tissue destruction [15].

LPS and other substances gain access to the gingival tissues, initiate and perpetuate immunoinflammation, resulting in production of high levels of proinflammatory cytokines. These induce production of matrix metalloproteinases which destroy the connective tissues of the gingiva and periodontal ligament, and prostaglandins which mediate alveolar bone destruction. Periodontitis may enhance susceptibility to systemic diseases in several ways. LPS and viable Gram-negative bacteria from the biofilms and pro-inflammatory cytokines from the inflamed periodontal tissues may enter the circulation in pathogenic quantities. In addition, periodontitis and certain systemic diseases (such as cardiovascular disease) share risk factors including tobacco smoking, male gender, race/ethnicity, stress, and aging [16].

\section{Production of Superoxide by LPS}

Polymorphonuclear leucocytes located at sites of microbial invasion are activated by inflammatory mediators, thereby generating increased levels of reactive oxygen species (ROS), which not only attack the pathogens but also host surrounding tissues [17]. The cascade of ROS production is initiated by the activity of a leucocyte membrane-bound enzyme called reduced nicotinamide adenine dinucleotide phosphate (NADPH) oxidase, which catalyses the reduction of molecular oxygen to superoxide anion $\left(\mathrm{O}_{2}^{-}\right)$. Successive mono electronic reductions of this radical generate hydrogen peroxide $\left(\mathrm{H}_{2} \mathrm{O}_{2}\right)$ and hydroxyl radical $\left(\mathrm{OH}^{-}\right)$; the latter being recognized as the most toxic amongst the oxygen species [17]. To restrict the molecular damage and to assure survival, the cells have evolved multiple mechanisms to decompose these species. Molecules such as ascorbic acid, $\alpha$-tocopherol, $\beta$ carotene, glutathione (GSH), thioredoxin, albumin, transferring and caeruloplasmin act in ROS scavenging and 
chelating transition metal ions, corresponding to the non-enzymatic mechanisms [18]. Superoxide dismutase (SOD) catalyses $\mathrm{O}_{2}{ }^{-}$dismutation to $\mathrm{H}_{2} \mathrm{O}_{2}$ which gets reduced to $\mathrm{H}_{2} \mathrm{O}$ by the action of catalase, glutathione peroxidase (GPx) and peroxiredoxins ( $\mathrm{Prx}$ ). Despite all these mechanisms, occasionally ROS formation surpasses the cellular defense system and oxidative stress is imposed, leading to severe periodontal tissue destruction [19]. A significant reduction of SOD activity has been found in saliva, gingival crevicular fluid (GCF), and serum in pre-eclamptic women with periodontal disease [20]. Similar SOD activities have been found in periapical granuloma and healthy gingival tissue [21]. Some studies have found that gingival SOD activity is significantly higher in chronic periodontitis $(\mathrm{CP})$, which suggested that SOD activity increases with the progression of inflammation [22]. Reduction in superoxide activity would therefore be beneficial in controlling inflammation leading to control of periodontal disease. Current studies show that NDM may have an effect on reduction of superoxide production which would in turn decrease periodontal destruction.

\section{Proanthocyanidin}

The cranberry (Vaccinium macrocarpon) is a native North American fruit that has recently received considerable attention in health research, particularly in the field of infectious diseases. Within the past 25 years, the body of scientific evidence to support that use has grown as investigations have shown that cranberry juice can prevent adherence of Escherichia coli bacteria to uroepithelial and other eukaryotic cells [23].

The biological activities of cranberry can be attributed to a diverse group of phytochemicals, including flavonoids, hydroxycinnamic acid derivatives, organic acids, and isoprenoids including ursolic acid and lutein. The flavonoids fall primarily into three classes: anthocyanins, flavonols, and proanthocyanidins (PACs) or polyflavan-3-ols.

Cranberry fruit PACs are primarily dimers, trimers, and larger oligomers of epicatechin, containing two types of linkages between epicatechin units: the more common being 4 $4 \mathrm{f} 8$ (B-type) linkage, also found in apples, grape seed, and cacao, and a less common A-type linkage featuring both $4 \beta \mathrm{f} 8$ and $2 \beta \mathrm{fOf} 7$ interflavonoid bonds that have been associated with the antibacterial adhesion properties of cranberry [24]. This unique structural feature has been associated with its anti-adhesion activity and its beneficial effects for prevention of urinary tract infections The A-type linkage in cranberry proanthocyanidins is an important structural feature in terms of bacterial anti-adhesion activity. A high-molecular-weight cranberry fraction was also reported to inhibit the scialic acid-specific adhesion of Helicobacter pylori to human gastric mucosa, a critical step for gastric ulcer development [25].

Although the primary role of PAC in plant physiology may have been protection

against pathogens or grazing herbivores, there has been a growing interest in PACs due to their antioxidant, anti-inflammatory, antibacterial, and anti-arthritic activities and their potential role in the prevention of heart disease, skin aging, and various cancers [26]. 
Bodet et al., investigated the effect of a proanthocyanidin-enriched cranberry fraction, prepared from cranberry juice concentrate, on inflammatory mediator production by gingival fibroblasts stimulated by the LPS of $A$. actinomycetemcomitans. IL-6, IL-8 and prostaglandin $\mathrm{E}_{2}\left(\mathrm{PGE}_{2}\right)$ production by fibroblasts treated with the cranberry fraction and stimulated by $A$. actinomycetemcomitans LPS was evaluated by enzyme-linked immunosorbent assay. The LPS-induced IL-6, IL-8, and PGE 2 responses of gingival fibroblasts were inhibited by treatment with the cranberry fraction. This fraction was found to inhibit fibroblast intracellular signaling proteins, a phenomenon that may lead to a down-regulation of activating protein-1 activity. Cranberry components also reduced cyclooxygenase 2 expression. Their study suggested that cranberry juice contains molecules with interesting properties for the development of new host-modulating therapeutic strategies in the adjunctive treatment of periodontitis [27].

In the area of dental research, it has been reported that a high molecular weight fraction prepared from cranberry juice inhibits the coaggregation of many oral bacteria [28] and affects dental biofilm formation [29, 30]. In addition, this cranberry fraction reduces Streptococci mutans levels in saliva, inhibits in vitro adhesion of Streptococcus sobrinus to hydroxyapatite [31], and promotes $S$. sobrinus desorption from artificial biofilms [23].

Bodet et al. investigated the effect of a high-molecular-weight cranberry fraction prepared from juice concentrate on the production by macrophages of pro-inflammatory cytokines and chemokines associated with periodontitis. The cytokine and chemokine responses of macrophages were induced by LPS prepared from E. coli, $A$. actinomycetemcomitans, $F$. nucleatum subsp. nucleatum, $P$. gingivalis, $T$. denticola, and $T$. forsythia. The non-dialyzable material (NDM) was considered as fraction one. Undialyzed concentrated juice was also lyophilized and represented fraction two. The macrophages were treated with lyophilized non-dialyzable material of cranberry juice concentrate i.e. fraction one or lyophilized cranberry juice concentrate i.e. fraction two prior to stimulation with the LPS of major periodontal pathogens. The results showed that TNF- $\alpha$ and IL- 6 responses of the macrophages stimulated by LPS from A. actinomycetemcomitans were significantly reduced by the treatments with fraction one ( 25 and $50 \mu \mathrm{g} / \mathrm{ml}$ ). This effect was not observed when the macrophages were treated with fraction two. Fraction one at a final concentration of $50 \mu \mathrm{g} / \mathrm{ml}$ inhibited the TNF- $\alpha$ and IL-6 responses of macrophages induced by the LPS of $F$. nucleatum subsp. nucleatum, as well as the TNF- $\alpha$ response induced by the LPS of E. coli. At low concentrations (10 and $25 \mu \mathrm{g} / \mathrm{ml}$ ), fraction one and the LPS of A. actinomycetemcomitans showed a synergistic effect on IL-1 $\beta$ production. However, at a concentration of 50 $\mu \mathrm{g} / \mathrm{ml}$, fraction one caused a significant reduction in LPS-induced IL-1 $\beta$ secretion by macrophages. This concentration-dependent effect on IL-1 $\beta$ production was also observed when macrophages were stimulated with the LPS of F. nucleatum subsp. nucleatum.

La et al. investigated the effects of A-type cranberry proanthocyanidins (ACPACs) on the production of various MMPs by human monocyte-derived macrophages stimulated with A.actinomycetemcomitans LPS and on the catalytic activity of 
recombinant MMP-1 and MMP-9. The effects of AC-PACs on the expression of five protein kinases and the activity of nuclear factor-kappa $\mathrm{B}(\mathrm{NF}-\kappa \mathrm{B})$ p65 in macrophages stimulated with LPS were also monitored. The results indicated that AC-PACs inhibited the production of MMPs in a concentration-dependent manner. The catalytic activity of MMP-1 and MMP-9 were also inhibited [32].

Labrecque et al. hypothesized that high-molecular-weight cranberry constituents may have a beneficial effect in the prevention of periodontitis by reducing growth and adherence of $P$. gingivalis. The effect of cranberry NDM on growth of $P$. gingivalis was determined using a plate diffusion assay. The cranberry NDM was added at various concentrations in THB-HK (Todd Hewitt Broth supplemented with Heme and Vit K) to determine its inhibitory effect on biofilm formation by $P$. gingivalis. The effect of cranberry NDM on the attachment properties of $P$. gingivalis was evaluated by a microplate assay in which mammalian proteins were immobilized into wells. The formation of biofilm was dose dependently inhibited by the cranberry fraction. A significant inhibition $(p<0.05)$ was observed when cranberry NDM was used at a concentration of $62.5 \mathrm{mg} / \mathrm{ml}$ and higher. The plate diffusion assay revealed that the cranberry NDM had no effect on the growth of $P$. gingivalis even at a concentration of $250 \mathrm{mg} / \mathrm{ml}$. Using a microplate assay in which proteins were immobilized on to the bottom of wells, $P$. gingivalis was found to attach to a similar extent to type I collagen, fibrinogen and human serum. The cranberry NDM caused a significant inhibition of $P$. gingivalis attachment to all three proteins when added at $50 \mathrm{mg} / \mathrm{ml}$. In conclusion, the data suggested that cranberry constituents may have a beneficial effect for the prevention and treatment of periodontitis by reducing the capacity of $P$.gingivalis to colonize periodontal sites [33].

Howel et al. examined the effects of AC-PACs on $P$. gingivalis growth and biofilm formation, adherence to human oral epithelial cells and protein coated surfaces, collagenase activity, and invasiveness. They also tested the ability of AC-PACs to modulate the $P$. gingivalis- induced inflammatory response by human oral epithelial cells. Their results showed that while AC-PACs neutralized all the virulence properties of $P$. gingivalis in a dose-dependent fashion; they did not interfere with growth. They were also found to inhibit the secretion of interleukin-8 (IL-8) and chemokine (C-C motif) ligand 5 (CCL5) but did not affect the secretion of IL-6 by epithelial cells stimulated with $P$. gingivalis. This anti-inflammatory effect was associated with reduced activation of the NF- $k$ B p65 pathway [34].

Steinberg et al. examined the effect of NDM on several constituents of the dental biofilm, glucosyltransferase (GTF), fructosyltransferase (FTF), as well as on the adhesion of Streptococcus sobrinus. The results demonstrated that the activity of immobilized and soluble GTF and FTF was inhibited by NDM. NDM also inhibited adhesion of S. sobrinus to hydroxyapatite. In conclusion, their results indicated that NDM may affect biofilm formation [29]. 


\section{CHAPTER 2. SPECIFIC OBJECTIVES}

The objective of this investigation was to study the effect of cranberry's non dialyzable material (NDM) which is shown to be rich in proanthocyanidins, on LPS biological activity such as its ability to stimulate cultured monocytic THP-1 cells to secrete inflammatory cytokines IL- $1 \beta, \mathrm{TNF}-\alpha$ and superoxide ions. LPS tested was isolated from three periodontal pathogens $P$. gingivalis, $T$.denticola, and $F$. nucleatum.

In this study we hypothesized that:

(1) LPS isolated from bacteria grown in the presence of NDM behaves differently in comparison to the normal LPS with respect to their ability to stimulate inflammatory cytokines.

(2) Incubation of THP-1 cells with NDM also interferes with secretion of cytokines when challenged with LPS.

(3) LPS ability to stimulate monocytic cells to secrete inflammatory cytokines in the presence of NDM will be lessened.

(4) NDM suppresses the LPS ability to stimulate the production of superoxide ions.

\section{Specific Aim 1}

To compare the ability of LPS isolated from $P$. gingivalis, $T$. denticola and $F$. nucleatum to stimulate THP-1 cells to secrete inflammatory cytokines IL- $1 \beta$ and TNF- $\alpha$ and to further investigate the influence of cranberry NDM component on this LPS-mediated induction of inflammatory cytokines.

Cytokines secreted by THP-1 cells in response to LPS were studied as follows:

(1) Growing the bacteria in NDM-supplemented culture media and isolating their LPS.

(2) Adding the NDM simultaneously along with LPS to the THP-1 cells.

(3) Incubating THP-1 cells with NDM prior to addition of LPS.

\section{Specific Aim 2}

To investigate whether the cranberry NDM has a suppressive function on LPS of periodontal pathogens-mediated secretion of $\mathrm{O}_{2}{ }^{-}$by cultured monocytes by measuring the percentage of superoxide dismutase inhibition.

Reactive oxygen species (ROS), $\mathrm{O}_{2}{ }^{-}$is constantly produced during metabolic processes. Under normal physiological conditions, cellular ROS generation is counterbalanced by the action of antioxidant enzymes and other redox molecules. The enzyme superoxide dismutase plays a crucial role in neutralization of ROS by catalyzing 
dismutation of superoxide anion into hydrogen peroxide and molecular oxygen. Cultured monocytic cells were incubated with LPS of periodontal pathogens in the presence of $\mathrm{NDM}$, and the release of superoxide ions was measured by calculating the quantity of superoxide dismutase that remained in the test samples. 


\section{CHAPTER 3. MATERIALS AND METHODOLOGY}

\section{Materials}

The bacteria, $P$. gingivalis (25260), $T$. denticola (33185), and $F$. nucleatum (10953), were obtained from ATCC, Rockville, MD. NDM was isolated from concentrated cranberry juice from Ocean Spray. The human myelogenous leukemia cell line THP-1 (22) were also obtained from ATCC. Limulus amebocyte lysate was purchased from the Associates of Cape Cod, Inc. (Boston, MA). Commercial enzymelinked immunosorbent assay (ELISA) kits from R\&D Systems (Minneapolis, MN) were employed to measure the cytokines IL- $1 \beta$ and TNF- $\alpha$ released by THP-1 cells. LPS from E. coli was purchased from Sigma-Aldrich, (St. Louis, MO). The SOD activity was calculated using the commercially available OxiSelect Superxoide Dismutase Acitivity Assay kit (Cellbio Labs, Inc; San Diego, CA.).

\section{Methodology}

\section{Cranberry NDM Preparation}

NDM was prepared as described previously [35] from concentrated cranberry juice made from the American cranberry, Vaccinium macrocarpon, and provided by Ocean Spray Cranberries, Inc. (Lakeville-Middleboro, MA). Briefly, NDM was obtained after lyophilization of the material retained in a dialysis bag (12,000 molecular weight cut-off) following extensive dialysis. The retentate of the bag designated NDM, is soluble in water up to $4 \mathrm{mg} / \mathrm{ml}$, and is devoid of proteins, carbohydrates, and fatty acids, and was found to exhibit tannin like properties suggesting that it is rich in phenolic compounds (e.g. proanthocyanidins) [36]. Further analysis was performed by Ocean Spray Inc. revealed that this fraction is devoid of sugars, acids, and nitrogen; containing $0.35 \%$ anthocyanins $(0.055 \%$ cyanidin- 3 -galactoside, $0.003 \%$ cyanidin- 3 -glucoside, $0.069 \%$ cyanidin-3-arabinoside, $0.116 \%$ peonidin-3-galactoside, $0.016 \%$ peonidin- 3 glucoside and $0.086 \%$ peonidin-3-arabinoside), and $65.1 \%$ proanthocyanidins [33, 37].

\section{LPS Preparation}

Periodontal pathogens were grown in liter batches of thioglycollate broth for 72 hours in an anaerobic jar. The bacteria were harvested by centrifugation and the cell pellets were washed with physiological saline, then with de-ionized water and centrifuged at (10,000xg, for 20 minutes). The bacterial cell pellets were lyophilized and the LPS were prepared by the hot phenol-water extraction method as described by Westphal and Jann [38]. Batches of $0.25 \mathrm{~g}$ of the lyophilized bacteria were suspended in $200 \mathrm{ml}$ of $90 \%$ phenol and hot water and then incubated at $67^{\circ} \mathrm{C}$ for 15 minutes; finally stirred for another 15 minutes on a stirrer at room temperature. The mixture was chilled on ice to 
$10^{\circ} \mathrm{C}$ to separate the phases. The resultant LPS-containing aqueous phase was then collected from the lower phenol phase. The non-aqueous phenol phase was subjected to a second extraction by adding an additional $200 \mathrm{ml}$ of water. The pooled aqueous phases were dialyzed against distilled water at $4^{\circ} \mathrm{C}$ for 48 hours. The aqueous phase was collected, and frozen; finally lyophilized. The purity and protein contamination of the isolated LPS was confirmed by gel electrophoresis (10\% polyacrylamide gel containing $0.1 \%$ sodium dodecyl sulfate). LPS samples were sonicated gently prior to electrophoresis, and then the gel was stained with silver nitrate stain.

To investigate the changes in biological activity of LPS, bacteria were grown in cultured medium supplemented with NDM (for $72 \mathrm{hrs}$ and then the LPS was isolated as described above.

\section{Limulus Amoebocyte Lysate (LAL) Assays}

The endotoxin activities of isolated LPS were measured first with the Limulus assay [39]. The Limulus endotoxin assay is a test developed from the blood cells of the horseshoe crab that detects minute amounts of endotoxins in fluids. All assays were conducted in 96-well microplates, using a computer-controlled BMG Lab tech Spectro star Nano ELISA reader. A turbidimetric assay was used in which the increasing turbidity caused by the gelation of the Limulus lysate in response to LPS was followed over time. Samples were prepared in a volume of $0.2 \mathrm{ml}$. LPS preparations from $T$. denticola, $F$. nucleatum, and $P$. gingivalis were suspended to concentrations of 0.1 to $100 \mathrm{ng} / \mathrm{ml}$. Highly purified LPS from E. coli K235 was used to prepare the standards over a concentration range of $0.1 \mathrm{ng} / \mathrm{ml}$ to $100 \mathrm{ng} / \mathrm{ml}$. The assay was initiated by addition of $50 \mu \mathrm{l}$ of Limulus lystate reagent to each well containing appropriate dilution of LPS. The samples were read at an absorbance of $450 \mathrm{~nm}$. Plots were made of the absorbance of each sample over time, and the curves were compared with those of the E. coli LPS standards. The activity of each LPS sample in causing gelation of Limulus lysate was expressed in units corresponding to the activity.

\section{Treatment of THP-1 Cells with LPS}

THP-1 cells were cultured in suspension in $75-\mathrm{cm}^{2}$ plastic tissue culture flasks (Corning Glass Works; Corning, NY) in RPMI 1640 (Invitrogen; Carlsbad, CA) culture medium. Human acute monocytic cell line THP-1 cells were incubated at $37^{\circ} \mathrm{C}$ in a humidified atmosphere consisting of $5 \% \mathrm{CO}_{2}$. The mature macrophage-like state of these cells were induced by treating THP- 1 cells $\left(10^{6}\right.$ cells per $\left.\mathrm{ml}\right)$ for $24 \mathrm{~h}$ with $\left(1 \times 10^{-7} \mathrm{M}\right)$ of phorbol 12-myristate 13-acetate (PMA; Sigma-Aldrich; St. Louis, MO.) in culture dishes. The transformed monocytes were incubated for 24 hours with different concentrations of LPS isolated from $P$. gingivalis, $T$. denticola, and $F$. nucleatum grown in the presence or absence of NDM. Culture supernatants were collected and assayed for the secreted cytokines. In order to study the effect of NDM on THP-1 cells, cells were first incubated with NDM for 60 minutes and then challenged with isolated LPS (10-20 $\mu \mathrm{g} / \mathrm{ml})$, and then incubated for 24 hours. The culture supernatants were collected for 
cytokine assays. In certain experiments both LPS and NDM were added at the same time to the THP-1 cells and processed in the same manner as described earlier.

\section{Cytokine Assays}

Collected supernatant fluids were assayed for secreted cytokines, IL-1 $\beta$ and TNF- $\alpha$ using ELISA kits. Manufacturer's suggested protocol was followed for assay. The plates were read using BMG Lab tech Spectro Star Nano ELISA reader at 490nm. Triplicate readings for each standard, control, and sample were taken and averaged. The average absorbance for each duplicate set of standards, controls, and samples were calculated by using a standard curve. Results were expressed as picograms of cytokines per milliliter of supernatant fluid.

\section{Superoxide Measurement}

Cultured supernatants from THP-1 cells $\left(10^{6}\right)$ after incubation with LPS $(10 \mathrm{ng} / \mathrm{ml})$ of isolated from periodontal pathogens were collected after four hours. These collected samples $(0.1 \mathrm{ml})$ were assayed for SOD activity using the commercially available OxiSelect Superoxide Dismutase Activity Assay kit. Briefly, the samples were mixed with xanthine solution, chromogen solution, and superoxide dismutase assay buffer, according to the manufacturer's protocol. They were then incubated at $37^{\circ}$ for 1 hour. The absorbance was read at $490 \mathrm{~nm}$ using BMG Lab tech Spectro Star Nano ELISA reader. A standard curve was prepared with superoxide dismutase activity as recommended. The percentage inhibition was calculated based on the standard curve. In order to test the effect of NDM on LPS mediated secretion of $\mathrm{O}_{2}^{-}$, cells were cultured with LPS and NDM $(20 \mu \mathrm{g} / \mathrm{ml})$ for four hours. The cultured supernatant was assayed for SOD activity as described above.

\section{Data Analysis}

Each experiment was repeated a minimum of three times, with triplicate determinations at each data point. Control media consisting of unstimulated THP-1 cells served as the negative control. The negligible amount of cytokine secretion and superoxide ions from the negative control detected in the assay were automatically subtracted from the values obtained in quantification of cytokines and superoxide ions secreted by THP-1 cells alone. Mean values \pm SEM from triplicate samples of all assays were calculated and the significance of differences were assessed using ANOVA followed by Scheffe's f-test. Differences in results with a $p$-value $<0.05$ were considered significant. 


\section{CHAPTER 4. RESULTS}

\section{Limulus Assay}

The endotoxin activities of LPS isolated from periodontal pathogens were measured first with the Limulus assay [40]. Stock solutions of LPS preparations from $E$. coli, $F$. nucleatum, $P$. gingivalis, and $T$. denticola were prepared in sterile water at $10 \mathrm{ng} / \mathrm{ml}$. These solutions were placed in an ultrasonic bath for 20 seconds prior to use to ensure a uniform suspension. Endotoxin activity was then tested in these samples by their ability to cause gelation of Limulus amoebocyte lysate over a period of 60 minutes. This is a standard measure of LPS or endotoxin activity. The Limulus assay uses a homogenate or lystate made from the macrophage-like amoebocytes taken from the blue blood (hemolymph) of the horseshoe crab (Limulus polyphemus). The lysate gels becomes turbid in the presence of endotoxins, the change in turbidity was measured at $450 \mathrm{~nm}$. This method has a high degree of sensitivity and can detect 0.001 to $100 \mathrm{ng} / \mathrm{ml}$ LPS. As a standard we used E. coli LPS. The activity of each LPS sample in causing gelation of Limulus lysate was expressed in units corresponding to the activity of $1 \mathrm{ng} / \mathrm{ml}$ of $E$. coli LPS. The results (see Fig. 4-1) show that all four LPS preparations demonstrated measurable endotoxin activity. The endotoxin activity of $F$. nucleatum, and $P$. gingivalis were almost identical, while the activity of $T$. denticola was slightly lower. The LPS activity of periodontal pathogens both had about one-third activity of the highly purified $E$. coli LPS standard.

\section{LPS Activity}

The THP-1 cells were treated with lipopolysaccharides isolated from periodontal pathogens $P$. gingivalis, $T$. denticola and $F$. nucleatum, and the cytokine activity was measured using the ELISA. The cells were challenged with 1, 2.5, 5, 7.5 and $10 \mathrm{ng} / \mathrm{ml}$ of LPS isolated from the above three periodontal pathogens. The concentration of TNF- $\alpha$ and IL- $1 \beta$ secreted by THP- 1 cells was measured in $\mathrm{pg} / \mathrm{ml}$. The study demonstrated in repeated experiments that the concentration of TNF- $\alpha$ and IL- $1 \beta$ secreted by THP- 1 cells was directly proportional to the concentration of LPS of all three periodontal pathogens.

Figure 4-2 demonstrates the secretion of TNF- $\alpha$ and IL- $1 \beta$ by THP- 1 cells that were treated with various concentrations of $P$. gingivalis LPS. The secretion of both cytokines TNF- $\alpha$ and IL- $1 \beta$ by THP- 1 cells was found to be dose dependent on the amount of LPS they were challenged with. Cultured monocytic cells secreted $110 \mathrm{pg} / \mathrm{ml}$ of TNF- $\alpha$, and $49 \mathrm{pg} / \mathrm{ml}$ of IL- $1 \beta$. Incubation of cells with $5 \mathrm{ng} / \mathrm{ml}$ and $10 \mathrm{ng} / \mathrm{ml}$ of LPS resulted in secretion of $332 \mathrm{pg} / \mathrm{ml}$ and $610 \mathrm{pg} / \mathrm{ml}$ of TNF- $\alpha$, respectively. In a similar fashion IL-1 $\beta$ secretion was measured to be 102 and $196 \mathrm{pg} / \mathrm{ml}$ by 5 and $10 \mathrm{ng} / \mathrm{ml}$ of LPS. 


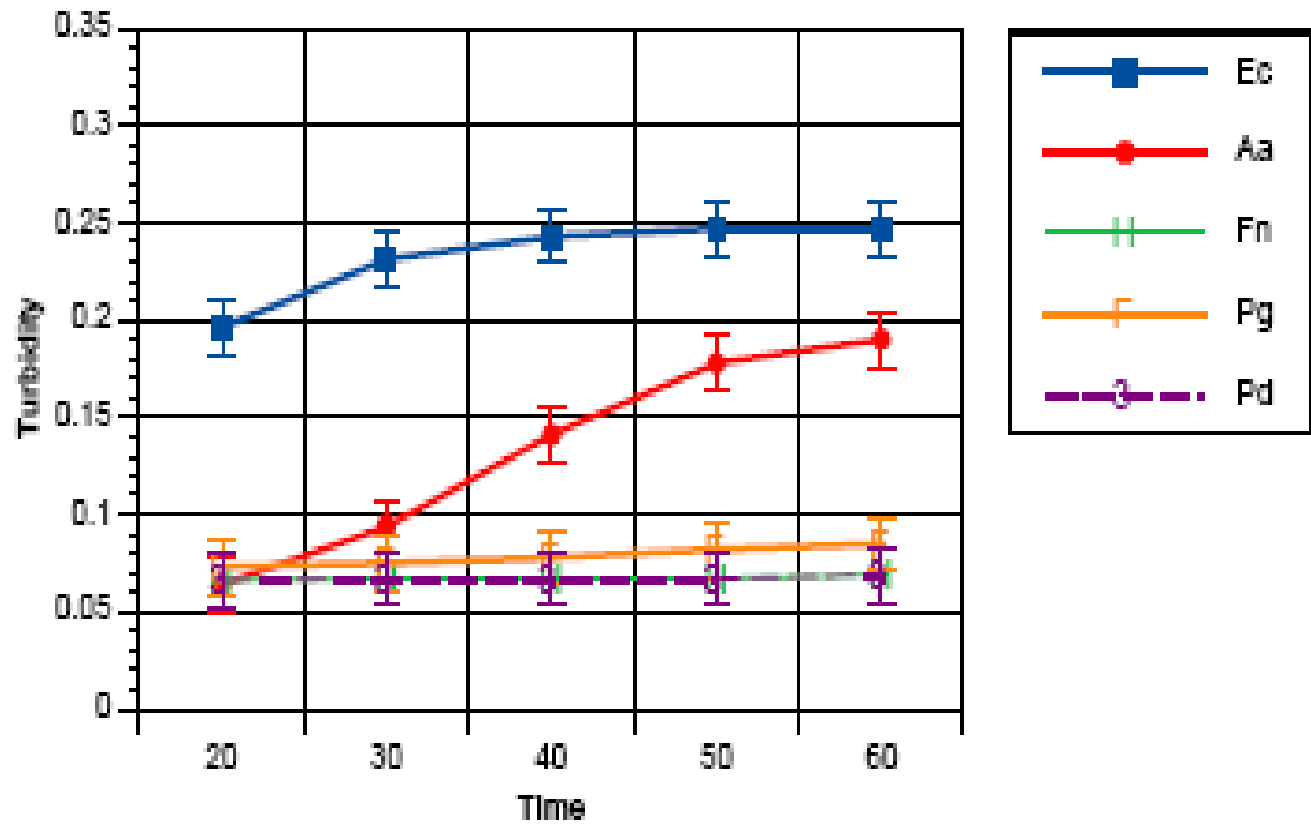

Figure 4-1. Endotoxin activity of LPS preparations from $E$. coli and oral pathogens at $10 \mathrm{ng} / \mathrm{ml}$. 


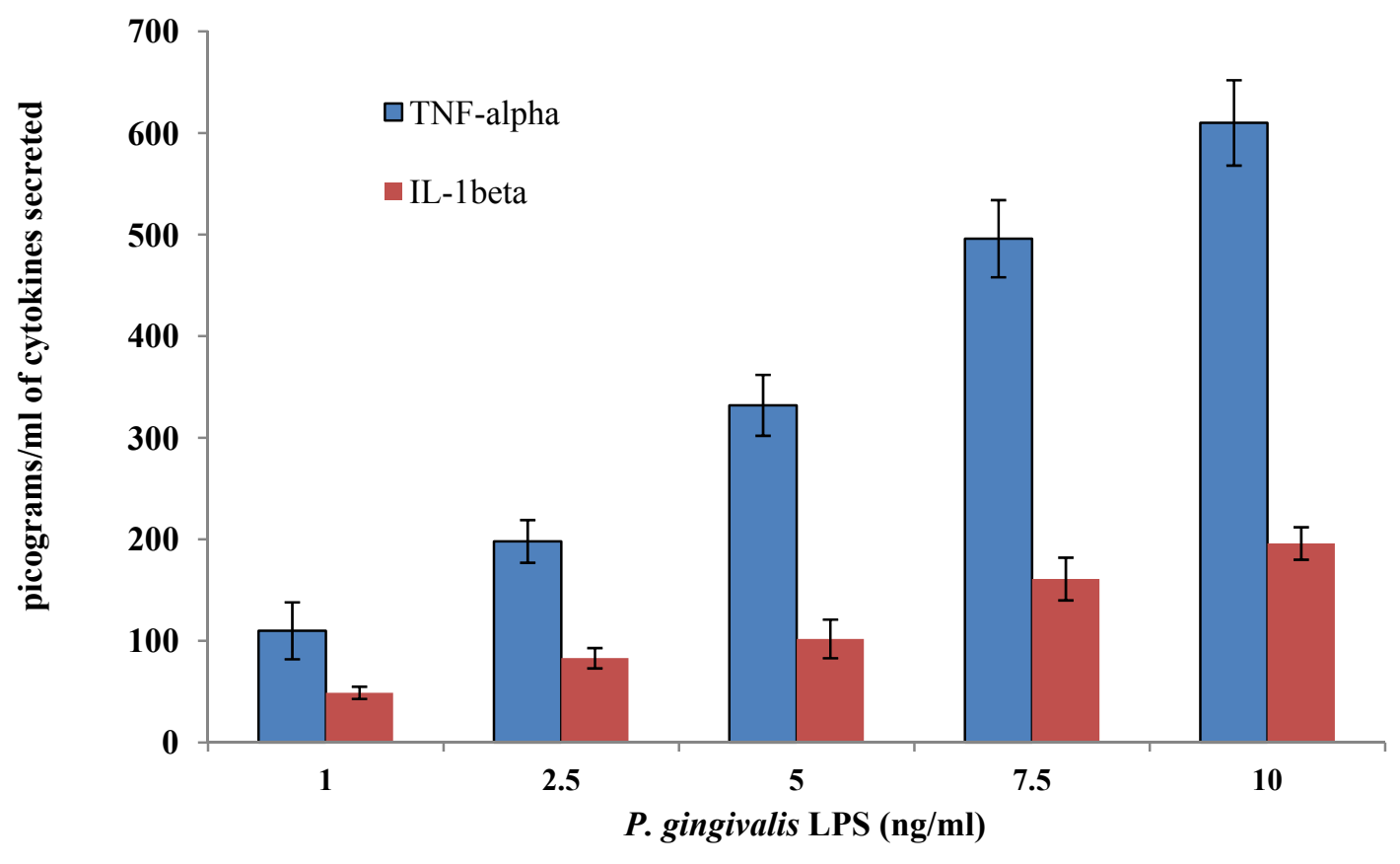

Figure 4-2. TNF- $\alpha$ and IL-1 $\beta$ secretion by THP-1 cells in response to $P$. gingivalis LPS. 
Figure 4-3 demonstrates the secretion of TNF- $\alpha$ and IL-1 $\beta$ by cultured THP-1 cells when incubated with LPS of $T$. denticola $(1.0,2.5,5.0,7.5$, and $10.0 \mathrm{ng} / \mathrm{ml})$. The quantity of cytokines secreted by cells was found to be proportional to the concentration of LPS used in the study. The cells secreted $627 \mathrm{pg} / \mathrm{ml}$ of TNF- $\alpha$ and $202 \mathrm{pg} / \mathrm{ml} \mathrm{IL-1 \beta}$ in presence of $10 \mathrm{ng} / \mathrm{ml}$ of LPS. On the other hand, substantially less was secreted in the presence of lower concentrations of LPS. Only $98 \mathrm{pg} / \mathrm{ml}$ of TNF- $\alpha$ and $37 \mathrm{pg} / \mathrm{ml}$ of IL-1 $\beta$ were secreted in the presence of $1 \mathrm{ng} / \mathrm{ml}$ of LPS.

Figure 4-4 shows the stimulation of cultured monocytes to secrete cytokines by varying concentrations of LPS isolated from $F$. nucleatum. Cells were incubated with 1 $\mathrm{ng} / \mathrm{ml}, 5 \mathrm{ng} / \mathrm{ml}, 7.5 \mathrm{ng} / \mathrm{ml}$, and $10 \mathrm{ng} / \mathrm{ml}$ of LPS. The secretion of both cytokines, TNF- $\alpha$ and IL-1 $\beta$, was found to be dose-dependent on the amount of LPS. Cultured monocytic cells when incubated with $1 \mathrm{ng} / \mathrm{ml}$ of LPS secreted $27 \mathrm{pg} / \mathrm{ml}$ of TNF- $\alpha$, and $24 \mathrm{pg} / \mathrm{ml}$ of IL-1 $\beta$. Incubation of cells with 5 and $10 \mathrm{ng} / \mathrm{ml}$ of LPS resulted in $84 \mathrm{pg} / \mathrm{ml}$ and $79 \mathrm{pg} / \mathrm{ml}$ of TNF- $\alpha$ and IL- $1 \beta$ respectively. Cells incubated with $10 \mathrm{pg} / \mathrm{ml}$ of LPS secreted significantly greater amounts of TNF- $\alpha$ (189 pg/ml), and IL-1 $\beta(172 \mathrm{pg} / \mathrm{ml})$.

\section{Secretion of TNF- $\alpha$ and IL-1 $\beta$ by THP-1 Cells Stimulated with LPS of $P$. gingivalis, T. denticola and $F$. nucleatum That Had Been Grown in the Presence or Absence of NDM}

The goal of this experiment was to determine whether bacteria mainly, $P$. gingivalis, $T$. denticola, and $F$. nucleatum that were grown in absence or presence of NDM for $72 \mathrm{hrs}$ in concentration of $10 \mu \mathrm{g} / \mathrm{ml}$ and $20 \mu \mathrm{g} / \mathrm{ml}$ had any effect on TNF- $\alpha$ and IL-1 $\beta$ production by THP-1 cells. An ELISA was employed to measure the concentration of the cytokines IL- $1 \beta$ and TNF- $\alpha$ secreted from THP-1 cells which were treated with bacterial LPS after 72 hrs of bacterial incubation with or without NDM.

Figure 4-5 shows the concentration of TNF- $\alpha$ and IL-1 $\beta$ secreted by THP-1 cells when stimulated with $P$. gingivalis LPS, when $P$. gingivalis was grown in presence or absence of NDM. Cells that were treated with $P$. gingivalis LPS isolated from bacteria grown in the absence of NDM $(10 \mathrm{ng} / \mathrm{ml})$ resulted in secretion of $667 \mathrm{pg} / \mathrm{ml}$ of TNF- $\alpha$ and $176 \mathrm{pg} / \mathrm{ml}$ of IL-1 $\beta$ respectively. When the cells were stimulated with LPS from bacteria grown in the presence of $10 \mathrm{ug} / \mathrm{ml}$ of NDM was added, $85 \%$ and $79 \%$ inhibition was seen for TNF- $\alpha$ and IL- $1 \beta$ respectively. As the concentration of NDM was, increased, a decrease was seen in the concentration of IL $1 \alpha$ and TNF- $\beta$ secreted by the THP-1 cells.

Figure 4-6 demonstrates the influence of $T$. denticola LPS, when the bacteria was previously incubated with NDM and then treated with THP-1 cells. Initial cytokine values were 582 and $191 \mathrm{pg} / \mathrm{ml}$ for TNF- $\alpha$ and IL-1 $\beta$ respectively. When the THP-1 cells were treated with $T$. denticola LPS from bacteria grown in the presence of $10 \mu \mathrm{g} / \mathrm{ml}$ of NDM a percent inhibition of 79 and $81 \%$ was seen with TNF- $\alpha$ and IL- $1 \beta$ respectively. Similar results were seen when the concentration was raised to $20 \mu \mathrm{g} / \mathrm{ml}$ of NDM. 


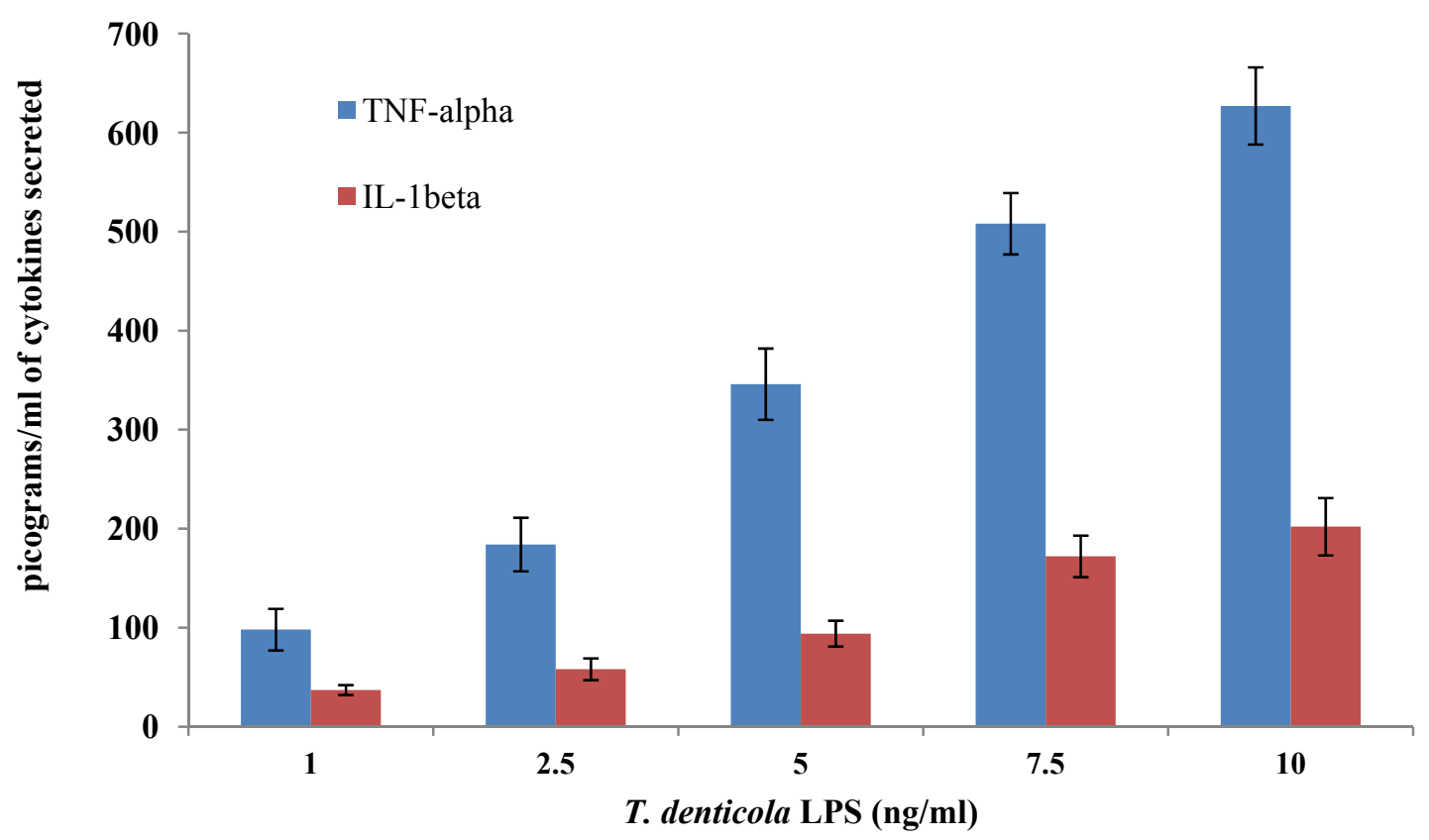

Figure 4-3. TNF- $\alpha$ and IL-1 $\beta$ secretion by THP-1 cells in response to $T$. denticola LPS. 


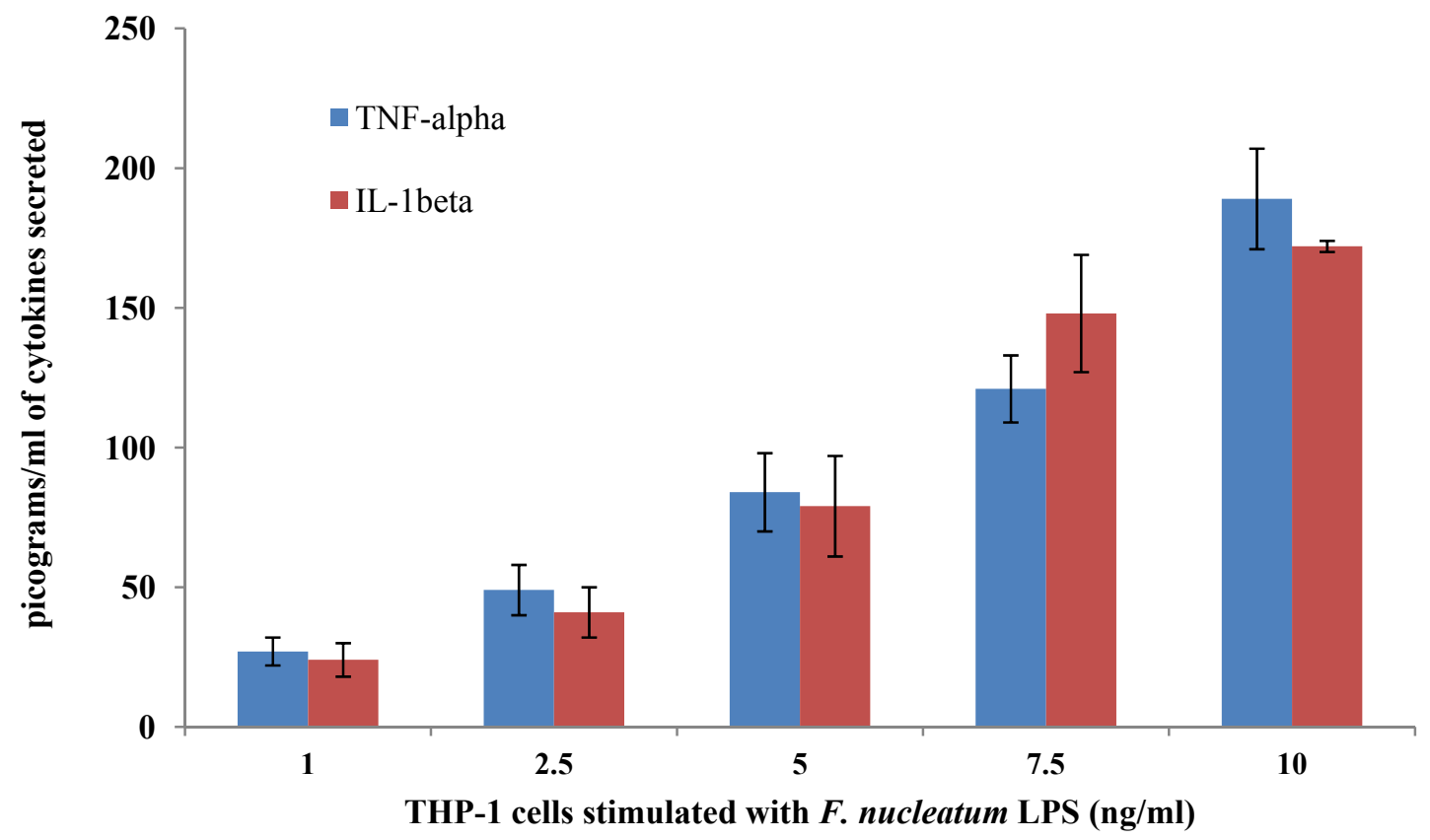

Figure 4-4. TNF- $\alpha$ and IL-1 $\beta$ secretion by THP-1 cells in response to $F$. nucleatum LPS. 


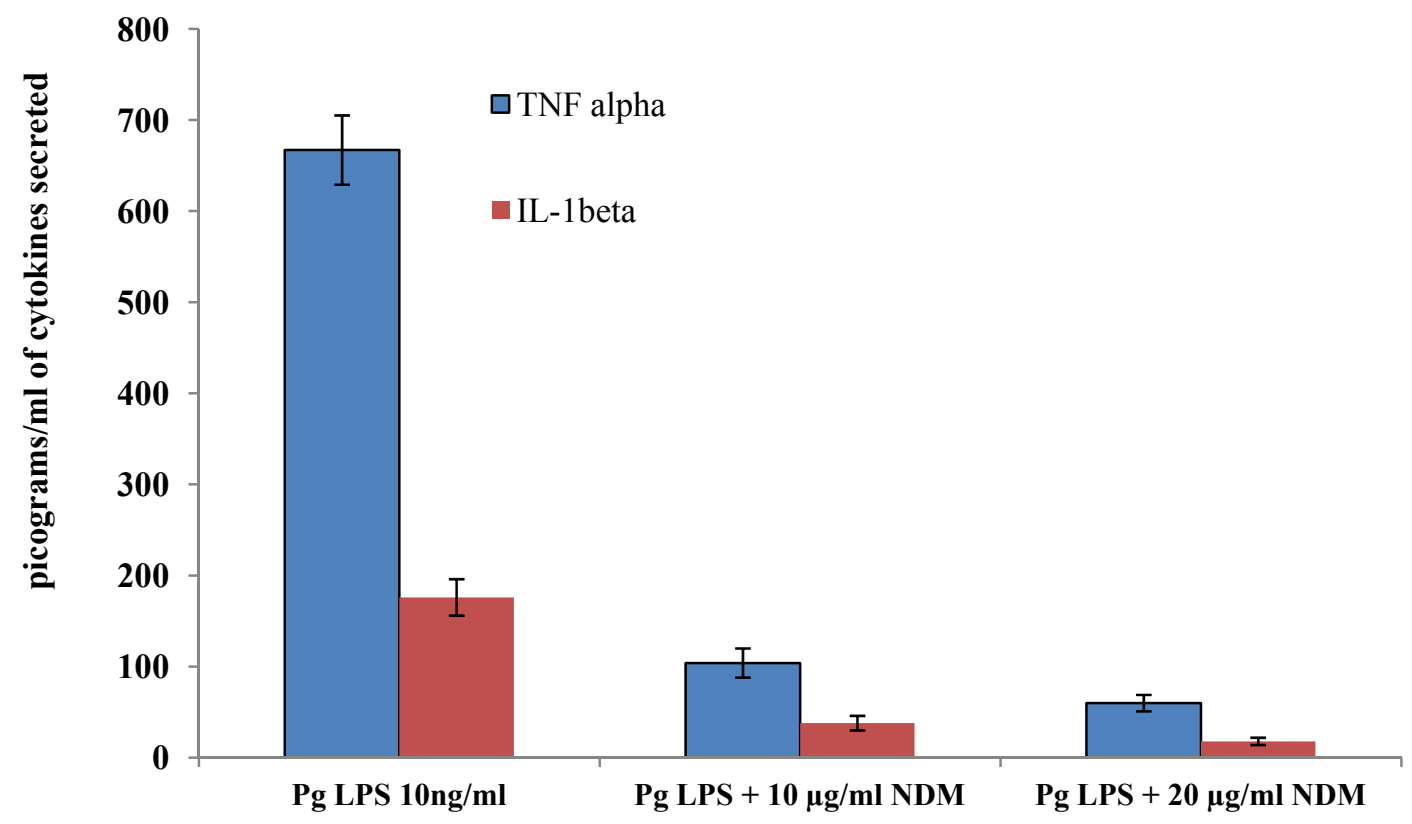

Figure 4-5. Secretion of TNF- $\alpha$ and IL-1 $\beta$ by THP-1 cells stimulated with LPS of $P$. gingivalis grown in presence or absence of NDM. 


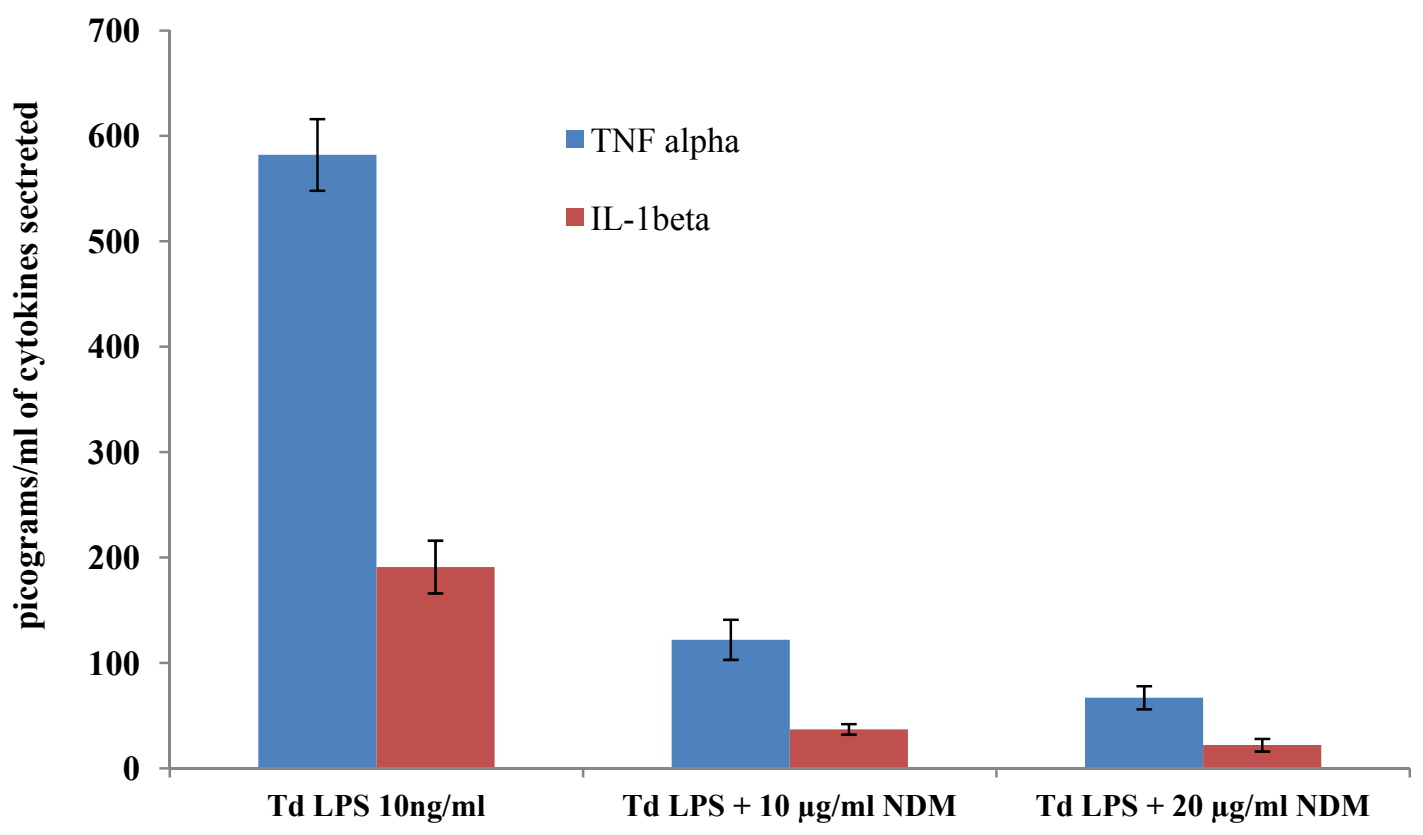

Figure 4-6. Secretion of TNF- $\alpha$ and IL-1 $\beta$ by THP-1 cells stimulated with LPS of $T$. denticola grown in presence or absence of NDM. 
Figure 4-7 shows the concentration of TNF- $\alpha$ and IL-1 $\beta$ secreted by THP-1 cells that were treated with $F$. nucleatum LPS, when $F$. nucleatum had been grown in absence or presence of NDM. THP-1 cells that had been treated with $F$. nucleatum LPS from bacteria grown $(10 \mathrm{ng} / \mathrm{ml})$ without the NDM secreted 487 and $165 \mathrm{pg} / \mathrm{ml}$ of TNF- $\alpha$ and IL-1 $\beta$ respectively. A decrease in cytokine secretion caused by LPS isolated from bacteria grown in the presence of NDM was observed, which was greater as the NDM concentration increased.

\section{TNF- $\alpha$ and IL-1 $\beta$ Secretion by the THP- 1 Cells When Both Bacterial LPS and NDM Were Added Simultaneously}

The goal of this experiment was to determine the effect on TNF- $\alpha$ and IL-1 $\beta$ secretion when THP -1 cells are treated simultaneously with bacterial LPS and NDM in concentration of $10 \mu \mathrm{g} / \mathrm{ml}$ and $20 \mu \mathrm{g} / \mathrm{ml}$. An ELISA was employed to measure the concentration of cytokines that were secreted from THP-1 cells which had been treated simultaneously with NDM and LPS of $P$. gingivalis, $T$. denticola, and F. nucleatum.

Figure 4-8 shows the effect of simultaneous exposure of NDM and LPS of $P$. gingivalis to THP-1 cells on the secretion of cytokines IL- $1 \alpha$ and TNF- $\beta$. Cultured monocytic cells secreted $197 \mathrm{pg} / \mathrm{ml}$ of TNF- $\alpha$ and $68 \mathrm{pg} / \mathrm{ml}$ of IL-1 $\beta$ when both NDM and LPS were added to the THP-1 cells; which represented decreases of $68 \%$ and $61 \%$ of TNF- $\alpha$ and IL-1 $\beta$ respectively, compared to the cells that were incubated with LPS alone.

Figure 4-9 demonstrates the THP-1 secretion of IL- $1 \alpha$ and TNF- $\beta$ when treated simultaneously with NDM and LPS of $T$. denticola. Cells incubated with $T$. denticola LPS $(10 \mathrm{ng} / \mathrm{ml})$ resulted in secretion of $512 \mathrm{pg} / \mathrm{ml}$ of TNF- $\alpha$ and $202 \mathrm{pg} / \mathrm{ml}$ of IL- $1 \beta$, respectively. When $10 \mu \mathrm{g} / \mathrm{ml}$ of NDM was added to cultured THP-1 cells along with $10 \mathrm{ng} / \mathrm{ml}$ of LPS, the amount of TNF- $\alpha$ secreted was inhibited by $65 \%$, and IL- $1 \beta$ secretion by $62 \%$. Incubation of the THP-1 cells and T. denticola LPS with $20 \mu \mathrm{g} / \mathrm{ml}$ of NDM resulted in greater degree of inhibition of the secretion of both IL-1 $\beta$ and TNF- $\alpha$ cytokines. A dose dependent decrease in concentration of TNF- $\alpha$ and IL-1 $\beta$ was seen as the NDM concentration was increased.

Figure 4-10 shows the influence of NDM and LPS of $F$. nucleatum on THP-1 cells to secrete cytokines, IL- $1 \beta$ and TNF- $\alpha$. Isolated LPS $(10 \mathrm{ng} / \mathrm{ml})$ of $F$. nucleatum resulted in secretion of $477 \mathrm{pg} / \mathrm{ml}$ of TNF- $\alpha$ and $172 \mathrm{pg} / \mathrm{ml}$ of IL-1 $\beta$. When LPS was added along with NDM $(10 \mu \mathrm{g} / \mathrm{ml})$ the secretion of both TNF- $\alpha$ and IL- $1 \beta$ was inhibited significantly $(\mathrm{p}<0.05)$. In the presence of $20 \mu \mathrm{g} / \mathrm{ml}$ of NDM cells secreted $66 \%$ less ofTNF- $\alpha$ and $88 \%$ less IL- $1 \beta$. 


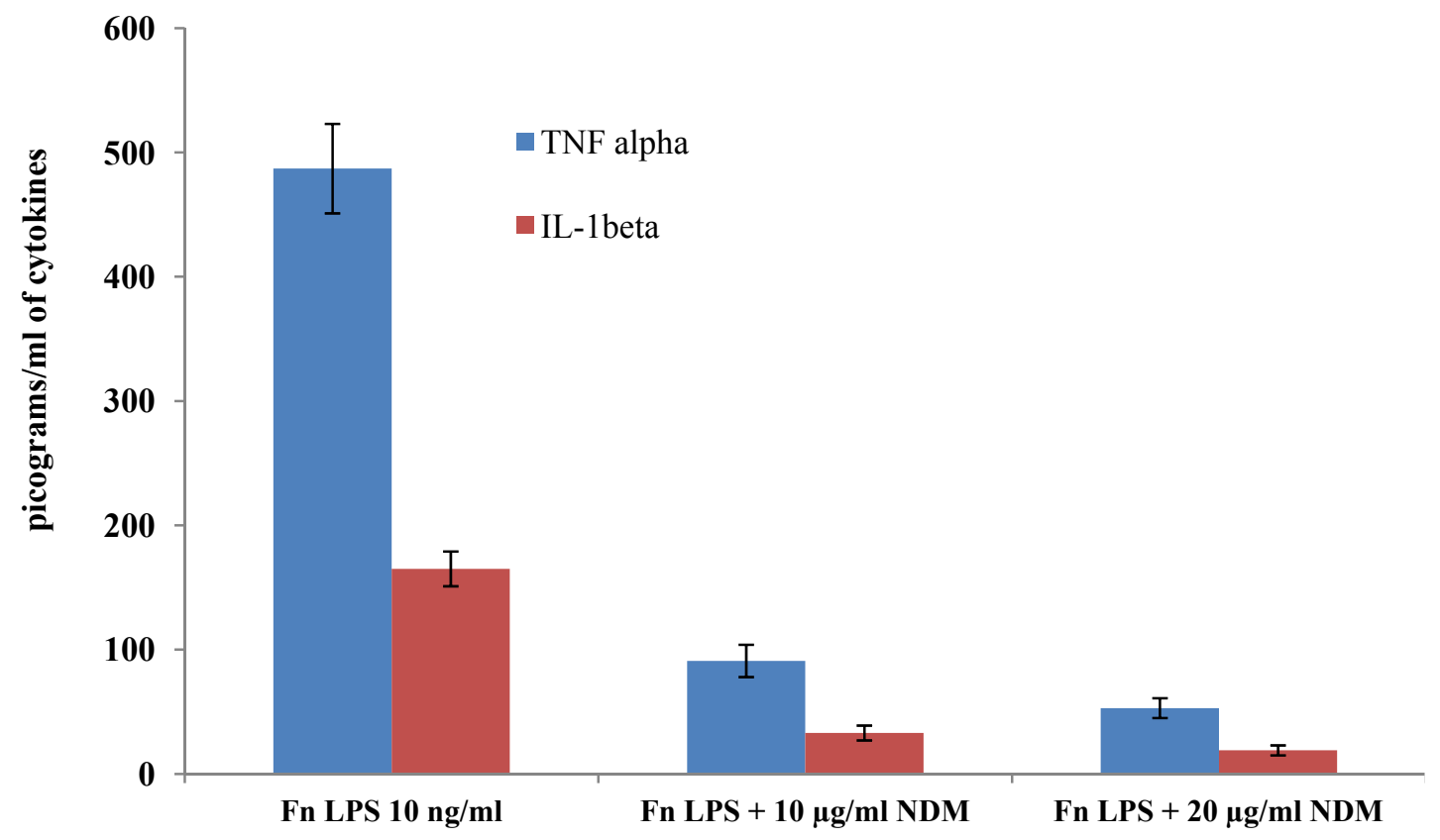

Figure 4-7. Secretion of TNF- $\alpha$ and IL-1 $\beta$ by THP-1 cells stimulated with LPS of $F$. nucleatum grown in presence or absence of NDM. 


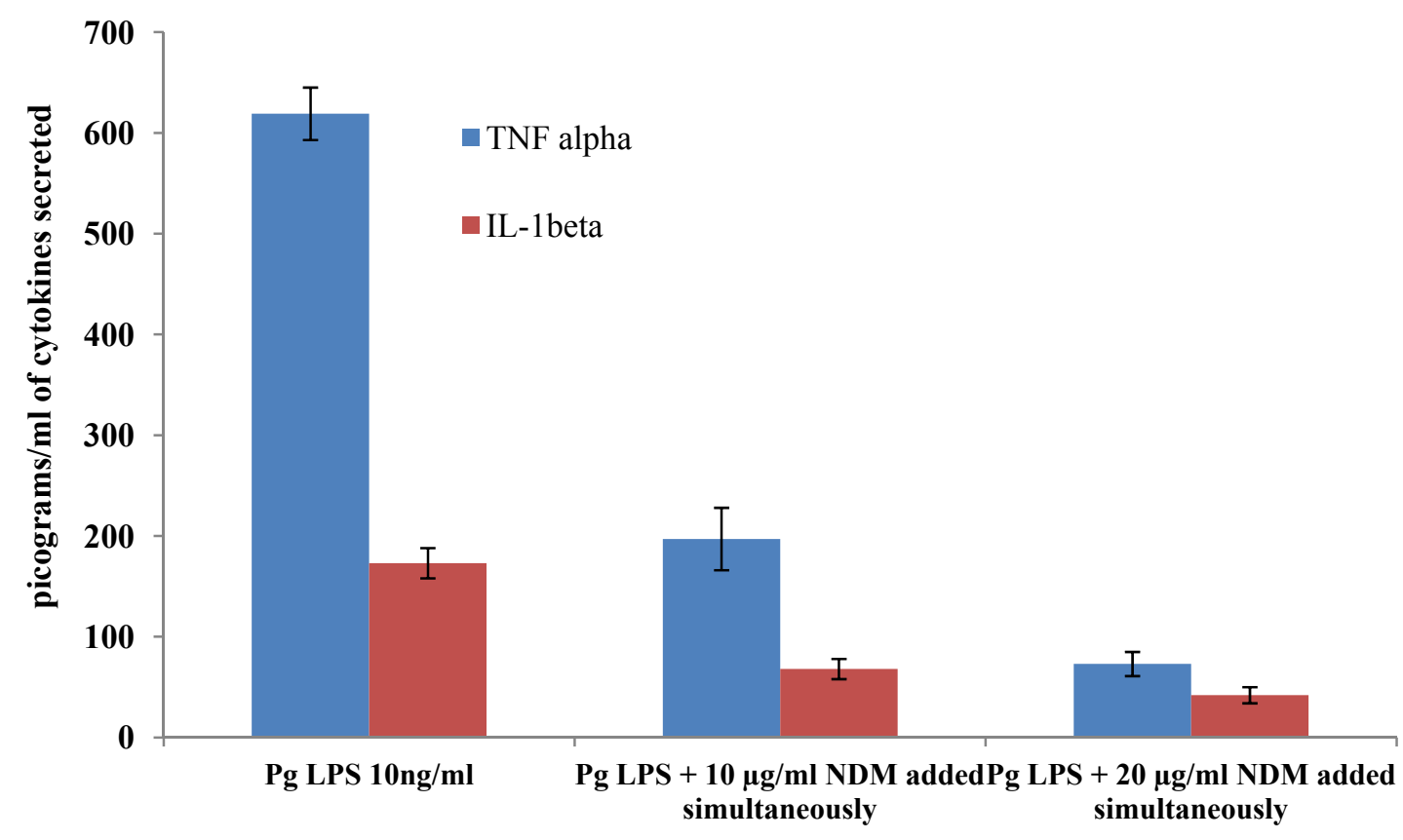

Figure 4-8. Concentration of TNF- $\alpha$ and IL-1 $\beta$ secreted by THP-1 cells that were stimulated with $P$. gingivalis LPS and NDM simultaneously. 


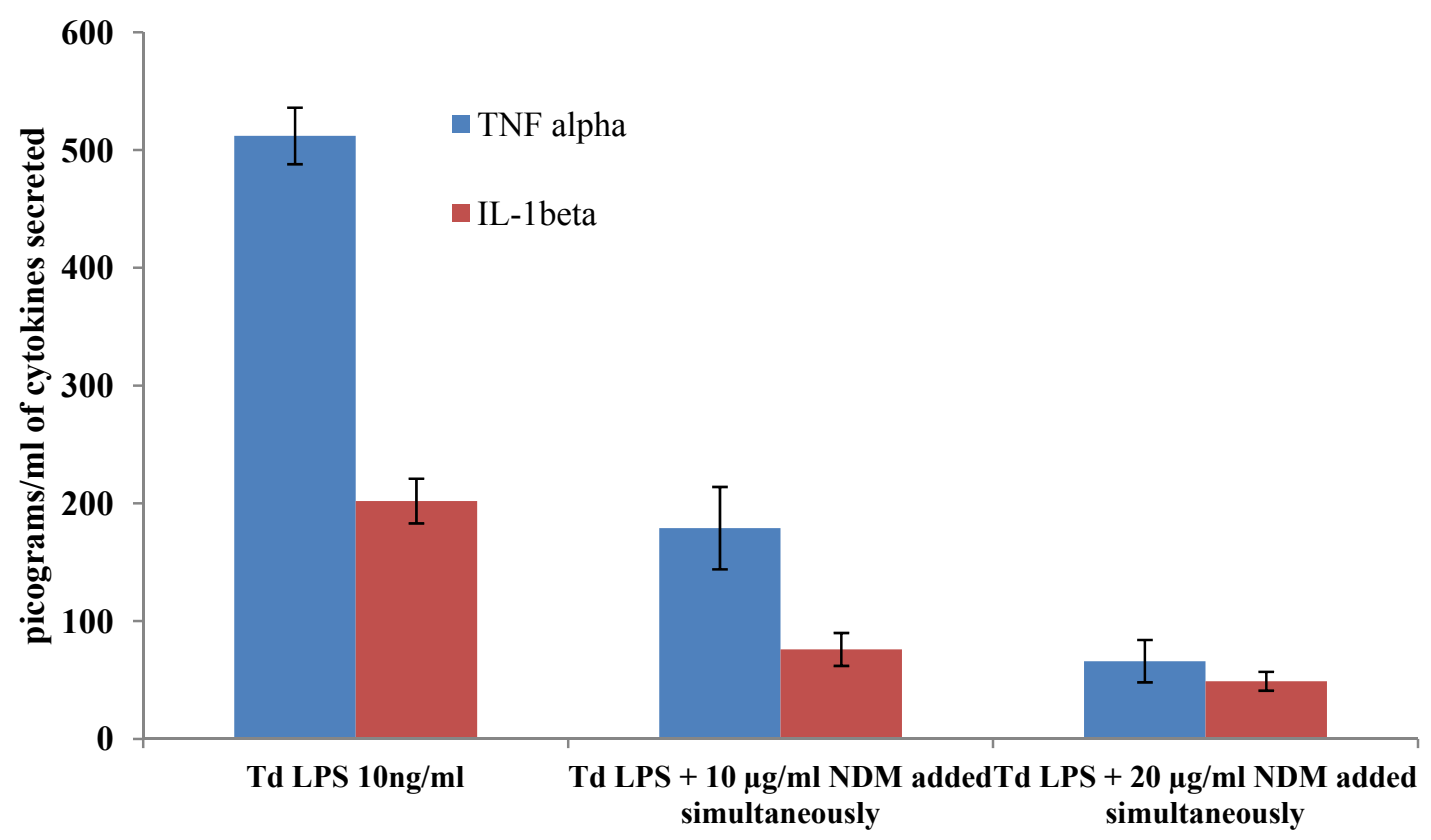

Figure 4-9. Concentration of TNF- $\alpha$ and IL-1 $\beta$ secreted by THP-1 cells that were stimulated simultaneously with $T$. denticola LPS and NDM. 


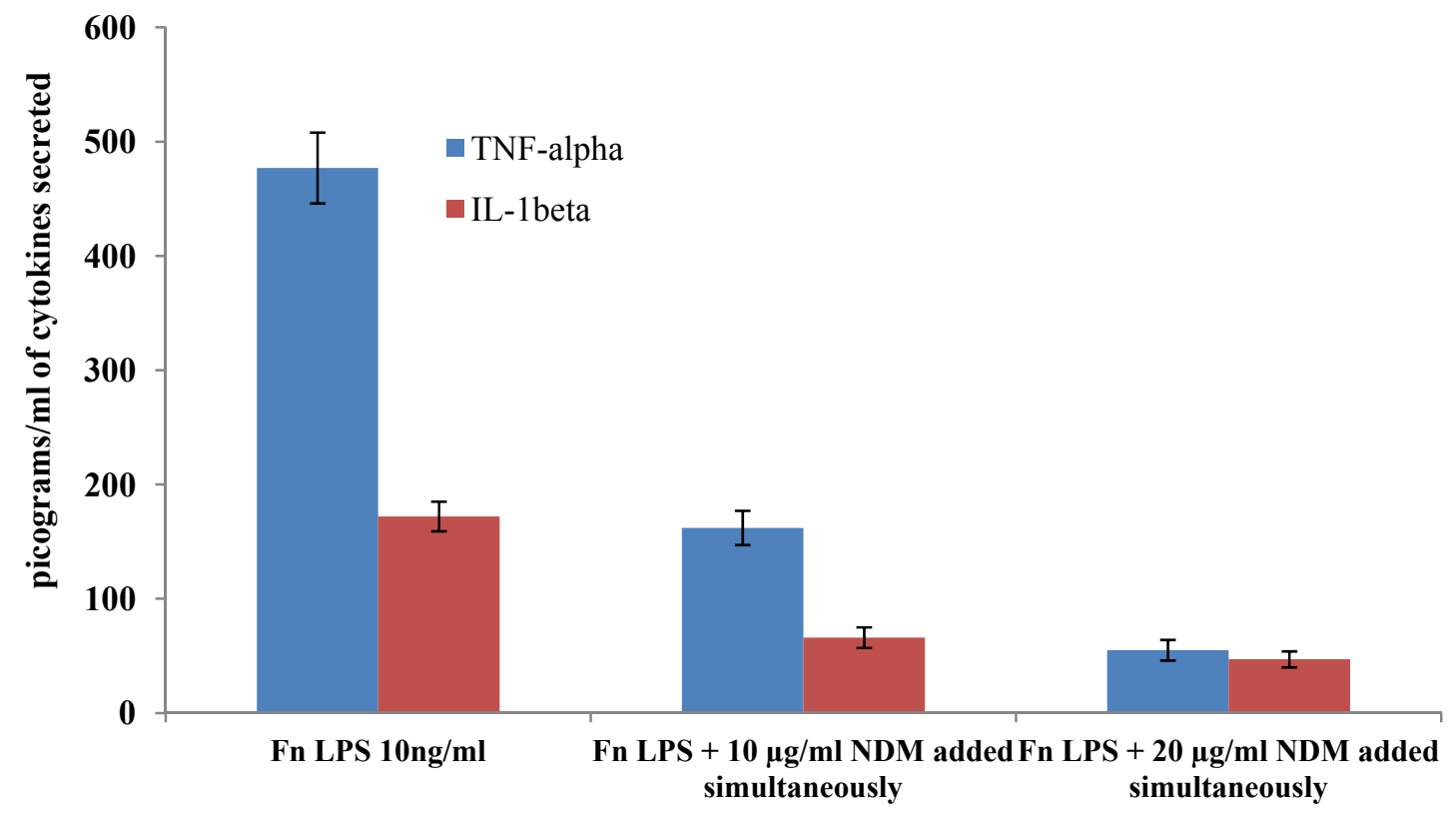

Figure 4-10. Concentration of TNF- $\alpha$ and IL-1 $\beta$ secreted by THP-1 cells that were stimulated simultaneously with $F$. nucleatum LPS and NDM. 


\section{TNF- $\alpha$ and IL-1 $\beta$ Secretion by THP-1 Cells When They Were Pre-Incubated with NDM for 60 Minutes and Then Stimulated with Bacterial LPS}

The goal of this experiment was to measure the secretion of IL- $1 \beta$ and TNF- $\alpha$ when the THP-1 cells were pre-incubated with 10 and $20 \mu \mathrm{g} / \mathrm{ml}$ of NDM and then stimulated by $P$. gingivalis, $T$. denticola, and $F$. nucleatum LPS. An ELISA was employed to measure the concentration of IL- $1 \beta$ and TNF- $\alpha$ secreted from THP- 1 cells.

Figure 4-11 demonstrates the stimulation of monocytic cells incubated first with NDM $(10-20 \mu \mathrm{g} / \mathrm{ml})$ prior to exposure to $P$. gingivalis LPS. THP-1 cells incubated first with NDM secreted significantly $(p<0.05)$ less TNF- $\alpha$ and IL-1 $\beta$ than the control cells which were not incubated with NDM. Cells secreted $628 \mathrm{pg} / \mathrm{ml}$ of TNF- $\alpha$ and $181 \mathrm{pg} / \mathrm{ml}$ of IL-1 $\beta$ in response to $10 \mathrm{ng} / \mathrm{ml}$ of LPS. On the other hand, when cells were incubated first with $10 \mu \mathrm{g} / \mathrm{ml}$ of NDM there was $84 \%$ decrease in TNF- $\alpha$ and $79 \%$ decrease in IL- $1 \beta$ secretion, respectively. The percent inhibition of cytokine secretion was increased when cells were incubated with $20 \mu \mathrm{g} / \mathrm{ml}$ of NDM.

Figure 4-12 shows the secretion of cytokines by THP-1 cells when pre-incubated for 60 minutes with NDM and then challenged with $T$. denticola LPS. It was seen that prior to incubation with NDM the THP-1 cells secreted $548 \mathrm{pg} / \mathrm{ml}$ of TNF- $\alpha$ and 189 $\mathrm{pg} / \mathrm{ml}$ of IL- $1 \beta$. When the cells were incubated first with NDM $(10 \mu \mathrm{g} / \mathrm{ml})$ for 60 minutes, they secreted $53 \%$ and $77 \%$ less TNF- $\alpha$ and IL-1 $\beta$, respectively. Cells incubated with $20 \mu \mathrm{g} / \mathrm{ml}$ of NDM secreted even less quantities of these cytokines.

Figure 4-13 demonstrates the effect of pre-incubation of THP-1 cells with NDM $(10-20 \mu \mathrm{g} / \mathrm{ml})$ on $F$. nucleatum LPS-mediated secretion of cytokines. Cultured monocytic cells (control) secreted 449 and $169 \mathrm{pg} / \mathrm{ml}$ of TNF- $\alpha$ and IL- $1 \beta$, respectively. Upon pre-incubation of THP-1 cells with $10 \mathrm{ng} / \mathrm{ml}$ of NDM, the cells secreted significantly lesser $(p<0.05)$ quantities of cytokines. Cells secreted $79 \%$ and $94 \%$ less of TNF- $\alpha$ when pre-incubated with 10 and $20 \mu \mathrm{g} / \mathrm{ml}$ of NDM, respectively. Secretion of IL-1 $\beta$ was also decreased in a similar fashion.

\section{Effect of Cranberry NDM on LPS-Induced Superoxide Production by THP-1 Cells}

The goal of this experiment was to determine the effect of NDM on LPS mediated secretion of superoxide ions by the THP-1 cells. For this study we chose to measure the enzyme level of SOD. The enzyme SOD regulates the levels of reactive oxygen species, such as O2-, when the levels increase due to infection and inflammation, the measurable SOD levels decrease as it is being consumed when it catalyzes O2- dismutation to $\mathrm{H} 2 \mathrm{O} 2$ which eventually gets reduced to $\mathrm{H} 2 \mathrm{O}$. Thus under conditions of stress or inflammation the levels of SOD in cellular system gets reduced drastically. In order to test the effect of NDM on LPS mediated stimulation of monocytic cells to secrete O2-, we measured the enzymatic level of SOD in the presence and absence of NDM when the THP-1 cells were stimulated with isolated LPS of periodontal pathogens. 


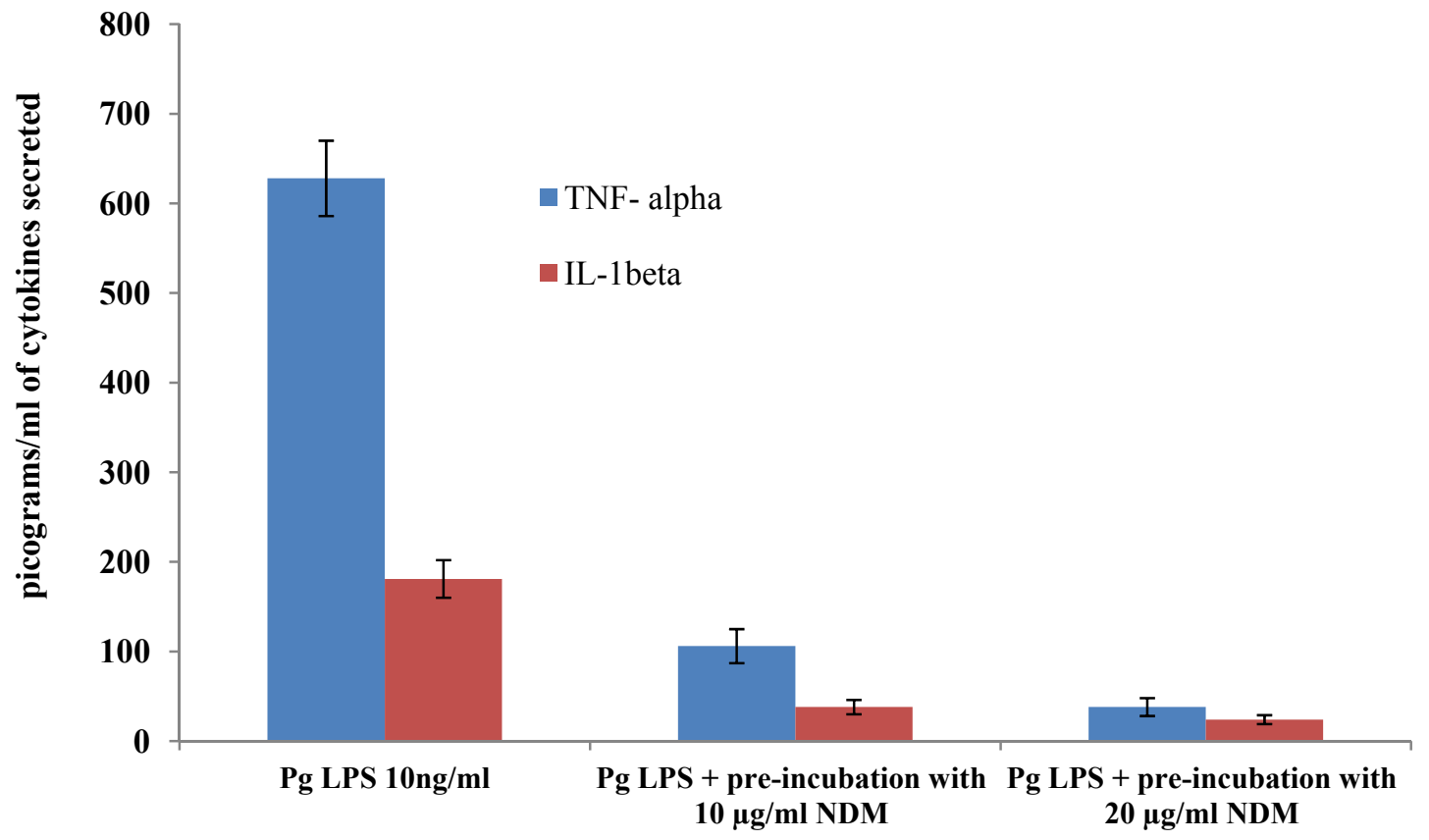

Figure 4-11. Concentration of TNF- $\alpha$ and IL-1 $\beta$ secreted by THP-1 cells that were pre-incubated for 60 minutes with 10 and $20 \mu \mathrm{g} / \mathrm{ml}$ of NDM and then stimulated with $P$. gingivalis LPS. 


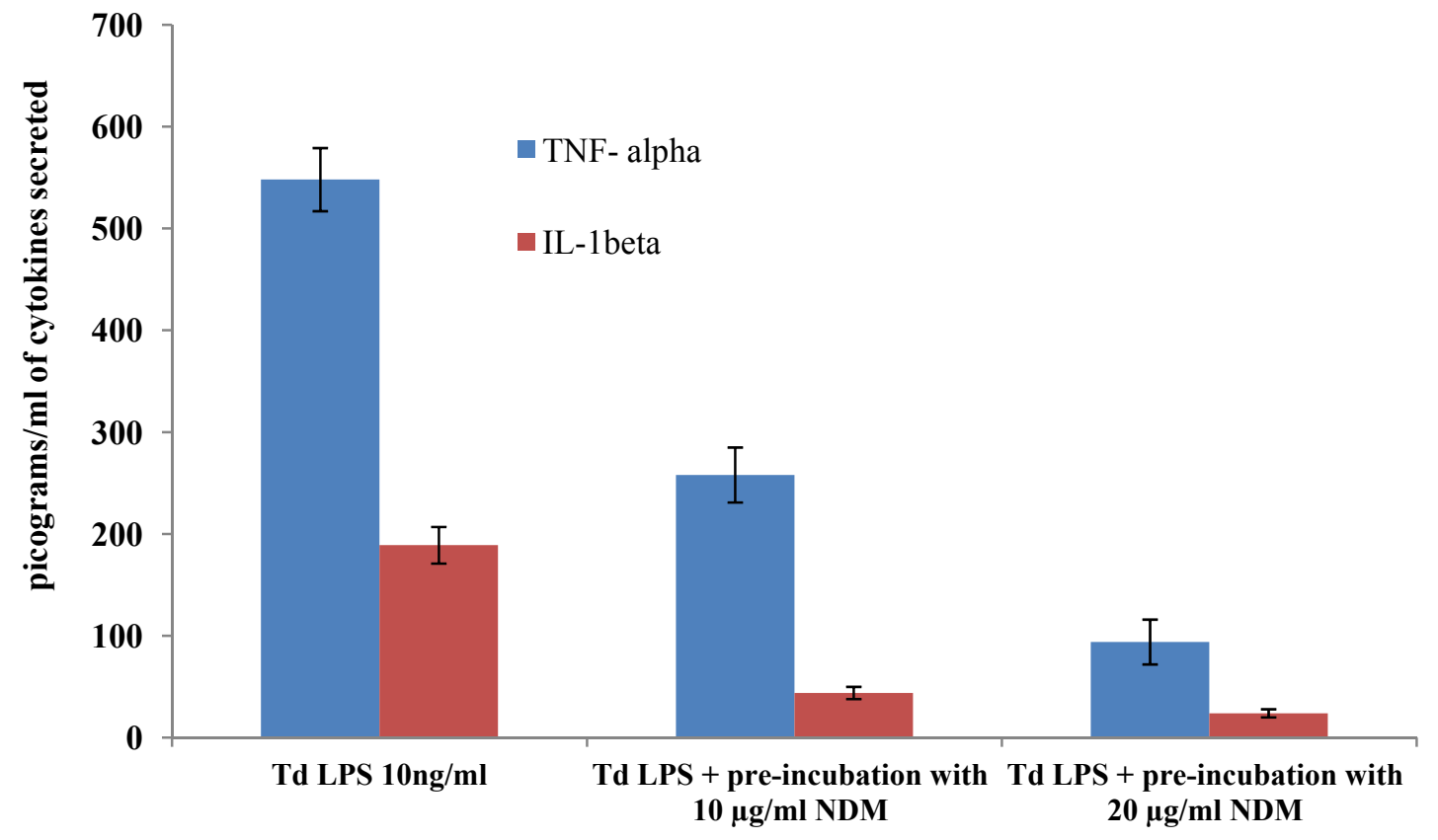

Figure 4-12. Concentration of TNF- $\alpha$ and IL-1 $\beta$ secreted by THP-1 cells that were pre-incubated for 60 minutes with 10 and $20 \mu \mathrm{g} / \mathrm{ml}$ of NDM and then stimulated with T. denticola LPS. 


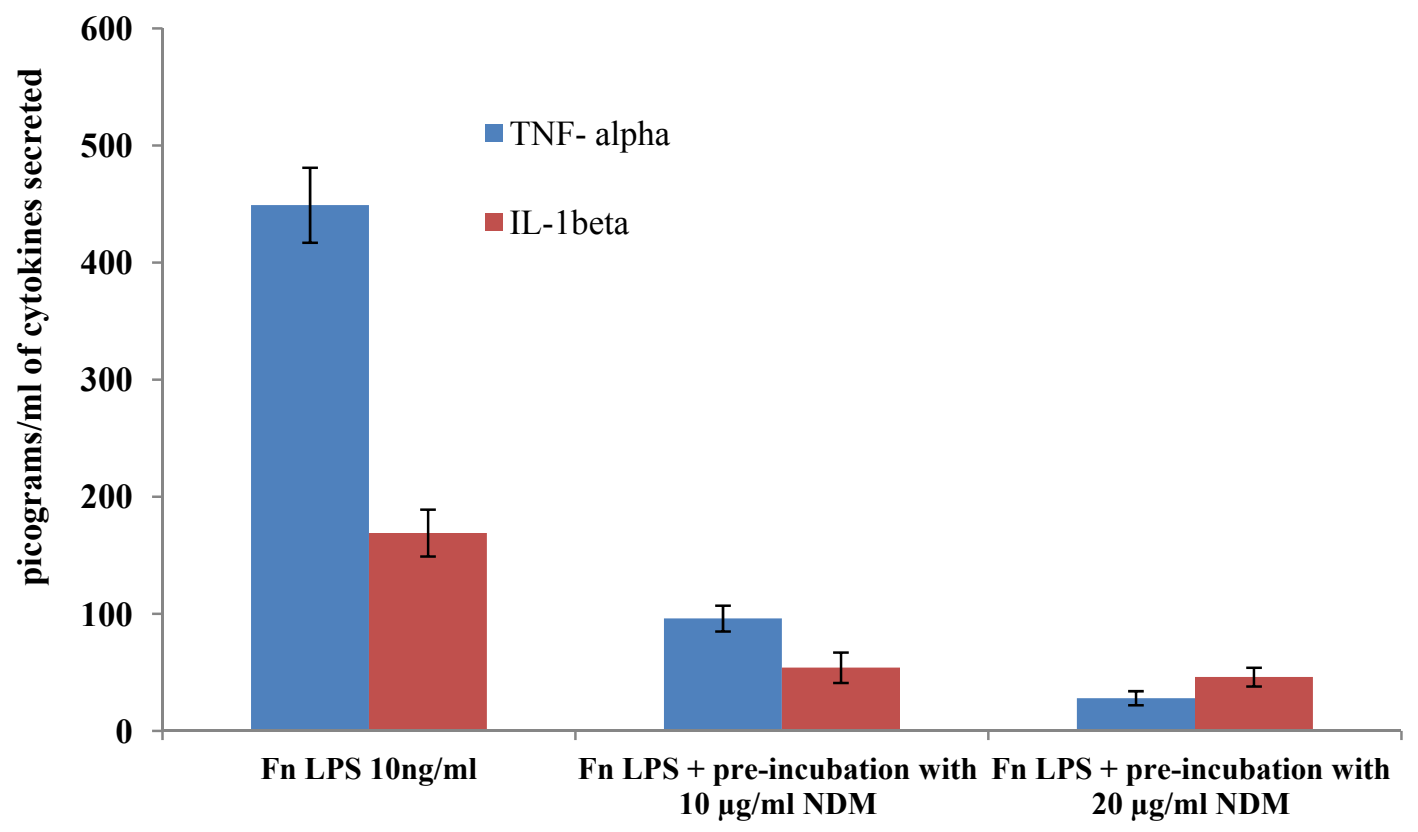

Figure 4-13. Concentration of TNF- $\alpha$ and IL-1 $\beta$ secreted by THP-1 cells that were pre-incubated for 60 minutes with 10 and $20 \mu \mathrm{g} / \mathrm{ml}$ of NDM and then stimulated with $F$. nucleatum LPS. 
Figure 4-14 demonstrates the effect of cranberry NDM on LPS-induced superoxide production by the THP-1 cells. The data shows that the LPS of all three organisms tested inhibited the SOD levels. About $81 \%$ inhibition of SOD levels was seen with $P$. gingivalis LPS, but in the presence of NDM the percentage of inhibition of SOD was reduced by approximately by $50 \%$. Both $T$. denticola and $F$. nucleatum LPS mediated inhibition of SOD levels was also reduced when NDM was added to the cells. The results suggest that NDM is capable of altering the LPS mediated release of $\mathrm{O}_{2}{ }^{-}$by the cultured monocytic cells. 


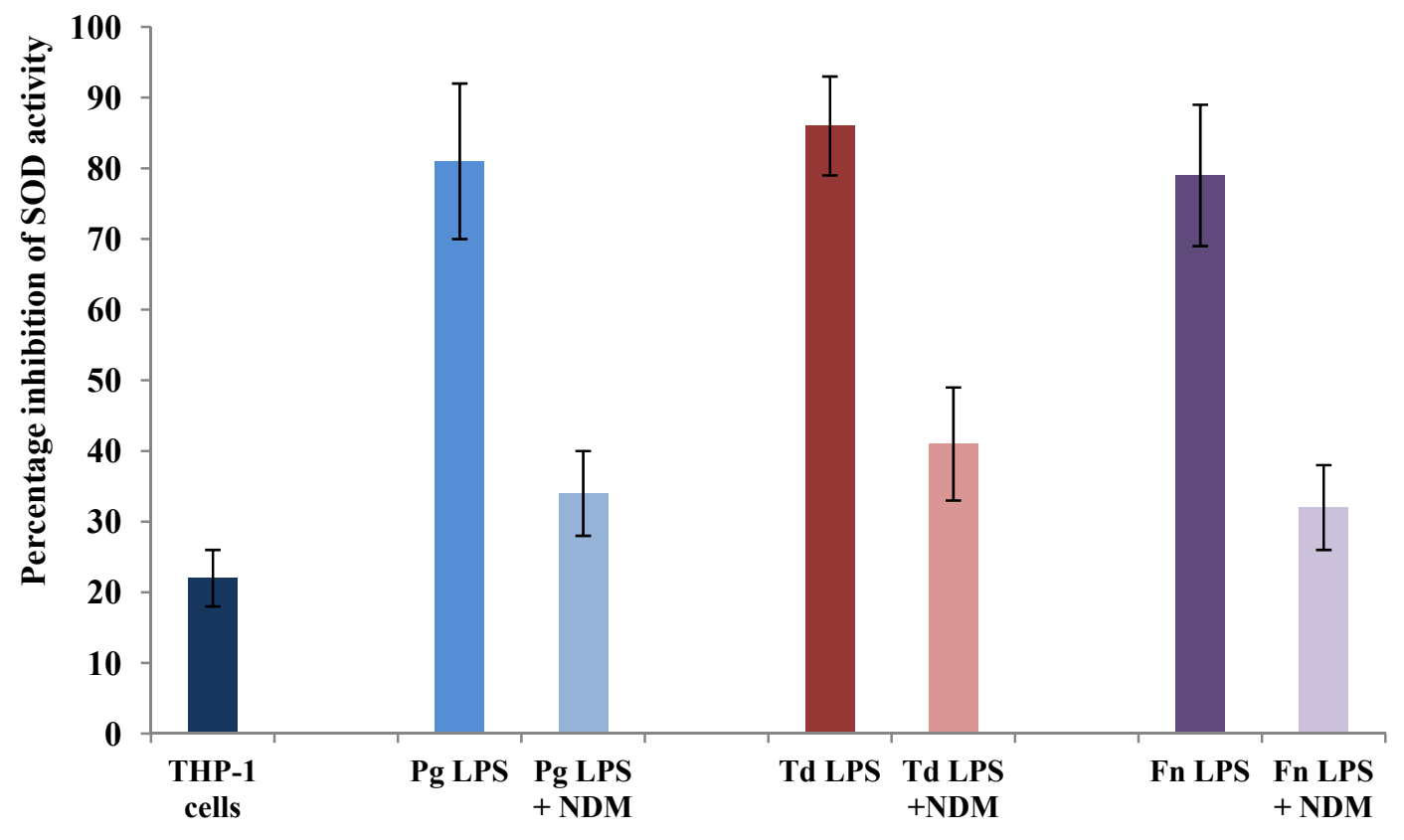

Figure 4-14. Effect of cranberry NDM on LPS-induced superoxide production by THP-1 cells. 


\section{CHAPTER 5. DISCUSSION}

The present study demonstrated the effects of cranberry NDM on LPS-mediated interactions with cultured monocytic cells. NDM appeared to interfere with secretion of inflammatory cytokines by the cultured monocytes in response to isolated LPS from periodontal pathogens. For the purpose of this study, LPS was isolated from oral pathogens, $P$. gingivalis, $T$. denticola, and $F$. nucleatum. NDM was also seen to interfere with superoxide ion release by the monocytes in response to LPS.

The three LPS samples demonstrated very similar endotoxin activity when tested with the Limulus assay. The results showed that the LPS endotoxin activity of periodontal pathogens was lower than that of LPS of E. coli. The first line of defense against an infection consists of the recruitment of monocytes and neutrophils. These cells are the most common leukocytes in circulating blood, representing greater than fifty percent of the cells. In this study cultured monocytes were exposed to the LPS isolated from $P$. gingivalis, $T$. denticola, and $F$. nucleatum the secreted inflammatory cytokines, TNF- $\alpha$ and IL-1 $\beta$,were measured. The results (see Fig. 4-2, 4-3 and 4-4) showed that the LPS of three oral pathogens induced the monocytes to secrete significant quantities of the two cytokines. This finding may be relevant to the previous study implicating the systemic inflammatory response as a major factor in severity of periodontitis, atherosclerosis and cardiovascular disease. Excessive secretion of inflammatory cytokines leads to irreversible destruction of tooth-supporting tissues, with tooth loss as a common end point [3]. It is very likely that periodontal pathogens cause oral pathogenesis by their ability to stimulate inflammatory cytokines with their LPS and may be a mechanism contributing to the severity of the disease.

\section{Cytokine Secretion by THP-1 Cells in Response to Isolated LPS of Periodontal Pathogens}

Cytokines, in particular IL-1, are potential markers of the progression and severity of periodontitis as well as indicators of an appropriate response to treatment [41]. It has been reported that cytokine synthesis inhibitors can reduce bone resorption in experimental periodontitis in rats [42]. Moreover, local inhibition of both IL-1 and TNF production in periodontal tissues significantly inhibits the inflammatory response and bone loss in ligature-induced periodontitis in monkeys [43]. This suggests that local inhibition of cytokines may be a successful approach for inhibiting bone resorption in periodontitis. In this study, we found that treating macrophages with the cranberry's nondialyzable material resulted in significant reduction in the secretion of both IL-1 $\beta$ and TNF- $\alpha$ cytokines (see Fig. 4.5 - 4.13). Our finding appears to agree with the previous study of Yang et al. [44], who demonstrated that green tea polyphenol-rich epigallocatechin gallate blocked mouse macrophage production of TNF- $\alpha$.

The growth and viability of $P$. gingivalis were found to be unaffected by cranberry NDM, which the chemical analysis indicated is enriched in complex phenolic 
polymers [33]. Similarly Ahuja et al., [45] reported that cranberry juice concentrate had no antibacterial activity on E. coli. A recent study by Babu et al. [46] demonstrated cranberry NDM did not affect viability of oral $S$. gordonii but inhibited bacterial metabolic activity. Taken together the results of our study and the existing literature attribute various beneficial roles of the cranberry NDM. It appears that NDM has the ability to inhibit the production of cytokines by the monocytic cells and also interferes with metabolic activity of the oral microorganisms as well as adhesion of certain bacteria.

The biological effect of LPS starts with its initial binding to LPS-binding protein (LBP) and CD14 [47-49]. The transfer of bacterial LPS by either mCD14 or sCD14 to a cell-associated TLR4 and MD-2 protein complex [50] initiates host cell activation pathways, leading to innate host defense mediator production, such as secretion of cytokines. When the THP-1 cells were incubated with NDM prior to LPS exposure, the quantity of cytokines secreted was significantly less than those secreted with LPS alone (see Fig. 4-11-4-13). It is possible that NDM may block the interaction of LPS with either LBP or with CD14 receptors. The LPS isolated from bacteria grown in the presence of NDM lead to a significant reduction in secretion of the cytokines. In this scenario it may be due to alteration of LPS structure or that NDM may render the lipid-A region of the LPS ineffective thus altering the biological function of LPS. The exact underlying mechanism by which the biological function of LPS is altered by NDM is far from clear. It would be beneficial to undertake further studies to delineate the mechanisms involved in the interference of LPS interaction with monocytic cells by the NDM. Nevertheless, it is important to note that cranberry NDM can alter the function of LPS in such a way that lesser quantities of cytokines are being secreted, which in turn may reduce the severity of periodontal disease.

\section{Reactive Oxygen Species (ROS)}

Free radicals can be defined as molecules or molecular fragments containing one or more unpaired electrons in atomic or molecular orbitals [51]. This unpaired electron(s) usually gives a considerable degree of reactivity to the free radical. Radicals derived from oxygen represent the most important class of radical species generated in living systems [52].

ROS and reactive nitrogen species (RNS, e.g. nitric oxide, NO) are well recognized for playing a dual role as both deleterious and beneficial species. ROS and RNS are normally generated by tightly regulated enzymes, such as NO synthase (NOS) and NADPH oxidase isoforms, respectively. Overproduction of ROS arising either from mitochondrial electron transport chain or excessive stimulation of NADPH results in oxidative stress, a deleterious process that can be an important mediator of damage to cell structures, including lipids and membranes, proteins, and DNA [53]. In contrast, beneficial effects of ROS/RNS (e.g. superoxide radical and nitric oxide) occur at low to moderate concentrations and involve physiological roles in cellular responses to noxia, for example in defense against infectious agents and in the function of 
a number of cellular signaling systems. One further beneficial example of ROS at low to moderate concentrations is the induction of a mitogenic response.

If a phagocytic cell such as the neutrophil is exposed to a stimulus, it has the ability of recognizing the foreign particle and undergoing a series of reactions called the respiratory burst [54]. Nicotine adenine dinucleotide phosphate (NADPH) oxidase is best characterized in neutrophils, where its production of $\mathrm{O}_{2}^{-}$generates the respiratory burst necessary for bacterial destruction.

Excessive respiratory burst was found to cause damage to cell structures, nucleic acids, lipids and proteins [18]. The hydroxyl radical is known to react with all components of the DNA molecule, damaging both the purine and pyrimidine bases and also the deoxyribose backbone [55]. Permanent modification of genetic material resulting from these "oxidative damage" incidents represents the first step involved in mutagenesis, carcinogenesis, and ageing [56].

In the present study it was demonstrated that the cranberry NDM appears to down-regulate the secretion of reactive oxygen radicals (superoxide ions) by the cultured monocytes in response to bacterial LPS. Addition of NDM along with LPS inhibited the amount of superoxide released by the cells, which was measured by the consumption of SOD. In this assay as the concentration of superoxide ions increases the levels of SOD decreases accordingly. NDM reduced the levels of superoxide ions released by the cells in response to all three LPS molecules tested. PACs have been shown to possess antiinflammatory property [34]. Based on our findings it is possible that the active component of NDM may be interfering with the release of superoxide ions by the cultured monocytes in response to LPS.

Naturally occurring biologically active compounds with the potential to modulate host responses are coming under considerable scrutiny since they have potential as new therapeutic agents for managing periodontal infections or reducing the severity of the disease. Cranberry NDM appears to be a promising candidate for the development of such therapies due to the demonstrated ability to inhibit secretion of inflammatory cytokines and superoxide radical ions. However, additional studies are required to identify the exact mechanisms by which the NDM exert its beneficial properties.

It is unlikely that the consumption of cranberry juice on its own can benefit oral health given the short contact time between the oral surfaces and the cranberry proanthocyanidins. It may prove more beneficial to add the NDM to oral hygiene products, which could then be tested for its potential for reducing the inflammation of the oral cavity when infected with oral pathogens. The use of naturally occurring compounds such as NDM may eventually reduce the need for antibiotics and help prevent the occurrence of bacterial resistance. 


\section{LIST OF REFERENCES}

1. Albandar, J.M., J.A. Brunelle, and A. Kingman, Destructive periodontal disease in adults 30 years of age and older in the United States, 1988-1994. J Periodontol, 1999. 70(1): p. 13-29.

2. Armitage, G.C., Periodontal diagnoses and classification of periodontal diseases. Periodontol 2000, 2004. 34: p. 9-21.

3. Darveau, R.P., A. Tanner, and R.C. Page, The microbial challenge in periodontitis. Periodontol 2000, 1997. 14: p. 12-32.

4. Socransky, S.S. and A.D. Haffajee, Implications of periodontal microbiology for the treatment of periodontal infections. Compend Suppl, 1994(18): p. S684-5, 688-93; quiz S714-7.

5. Listgarten, M.A., Structure of the microbial flora associated with periodontal health and disease in man. A light and electron microscopic study. J Periodontol, 1976. 47(1): p. 1-18.

6. $\quad$ Socransky, S.S., et al., Microbial complexes in subgingival plaque. J Clin Periodontol, 1998. 25(2): p. 134-44.

7. Kornman, K.S., R.C. Page, and M.S. Tonetti, The host response to the microbial challenge in periodontitis: assembling the players. Periodontol 2000, 1997. 14: $\mathrm{p}$. 33-53.

8. Gemmell, E., R.I. Marshall, and G.J. Seymour, Cytokines and prostaglandins in immune homeostasis and tissue destruction in periodontal disease. Periodontol 2000, 1997. 14: p. 112-43.

9. Graves, D.T. and D. Cochran, The contribution of interleukin-1 and tumor necrosis factor to periodontal tissue destruction. J Periodontol, 2003. 74(3): p. 391-401.

10. Stewart, I., P.J. Schluter, and G.R. Shaw, Cyanobacterial lipopolysaccharides and human health - a review. Environ Health, 2006. 5: p. 7.

11. Kumada, H., et al., Biological properties of the native and synthetic lipid $A$ of Porphyromonas gingivalis lipopolysaccharide. Oral Microbiol Immunol, 2008. 23(1): p. 60-9.

12. Wang, P.L. and K. Ohura, Porphyromonas gingivalis lipopolysaccharide signaling in gingival fibroblasts-CD14 and Toll-like receptors. Crit Rev Oral Biol Med, 2002. 13(2): p. 132-42. 
13. Hajishengallis, G., et al., Interactions of oral pathogens with toll-like receptors: possible role in atherosclerosis. Ann Periodontol, 2002. 7(1): p. 72-8.

14. Kocgozlu, L., et al., Variable cell responses to P. gingivalis lipopolysaccharide. J Dent Res, 2009. 88(8): p. 741-5.

15. Okada, H. and S. Murakami, Cytokine expression in periodontal health and disease. Crit Rev Oral Biol Med, 1998. 9(3): p. 248-66.

16. Page, R.C., The pathobiology of periodontal diseases may affect systemic diseases: inversion of a paradigm. Ann Periodontol, 1998. 3(1): p. 108-20.

17. Nagata, M., Inflammatory cells and oxygen radicals. Curr Drug Targets Inflamm Allergy, 2005. 4(4): p. 503-4.

18. Valko, M., et al., Free radicals and antioxidants in normal physiological functions and human disease. Int J Biochem Cell Biol, 2007. 39(1): p. 44-84.

19. Chapple, I.L. and J.B. Matthews, The role of reactive oxygen and antioxidant species in periodontal tissue destruction. Periodontol 2000, 2007. 43: p. 160-232.

20. Canakci, V., et al., Total antioxidant capacity and antioxidant enzymes in serum, saliva, and gingival crevicular fluid of preeclamptic women with and without periodontal disease. J Periodontol, 2007. 78(8): p. 1602-11.

21. Marton, I.J., et al., The role of reactive oxygen intermediates in the pathogenesis of chronic apical periodontitis. Oral Microbiol Immunol, 1993. 8(4): p. 254-7.

22. Akalin, F.A., E. Toklu, and N. Renda, Analysis of superoxide dismutase activity levels in gingiva and gingival crevicular fluid in patients with chronic periodontitis and periodontally healthy controls. J Clin Periodontol, 2005. 32(3): p. 238-43.

23. Sobota, A.E., Inhibition of bacterial adherence by cranberry juice: potential use for the treatment of urinary tract infections. J Urol, 1984. 131(5): p. 1013-6.

24. Patel, K.D., et al., Proanthocyanidin-rich extracts from cranberry fruit (Vaccinium macrocarpon Ait.) selectively inhibit the growth of human pathogenic fungi Candida spp. and Cryptococcus neoformans. J Agric Food Chem, 2011. 59(24): p. 12864-73.

25. Burger, O., et al., A high molecular mass constituent of cranberry juice inhibits helicobacter pylori adhesion to human gastric mucus. FEMS Immunol Med Microbiol, 2000. 29(4): p. 295-301. 
26. Khanal, R.C., L.R. Howard, and R.L. Prior, Procyanidin content of grape seed and pomace, and total anthocyanin content of grape pomace as affected by extrusion processing. J Food Sci, 2009. 74(6): p. H174-82.

27. Bodet, C., F. Chandad, and D. Grenier, Cranberry components inhibit interleukin6, interleukin-8, and prostaglandin E production by lipopolysaccharide-activated gingival fibroblasts. Eur J Oral Sci, 2007. 115(1): p. 64-70.

28. Weiss, E.I., et al., Inhibiting interspecies coaggregation of plaque bacteria with a cranberry juice constituent [published erratam appear in J Am Dent Assoc 1999 Jan;130(1):36 and 1999 Mar;130(3):332]. J Am Dent Assoc, 1998. 129(12): p. 1719-23.

29. Steinberg, D., et al., Effect of a high-molecular-weight component of cranberry on constituents of dental biofilm. J Antimicrob Chemother, 2004. 54(1): p. 86-9.

30. Yamanaka, A., et al., Inhibitory effects of cranberry juice on attachment of oral streptococci and biofilm formation. Oral Microbiol Immunol, 2004. 19(3): p. 1504.

31. Weiss, E.I., et al., A high molecular mass cranberry constituent reduces mutans streptococci level in saliva and inhibits in vitro adhesion to hydroxyapatite. FEMS Microbiol Lett, 2004. 232(1): p. 89-92.

32. La, V.D., A.B. Howell, and D. Grenier, Cranberry proanthocyanidins inhibit MMP production and activity. J Dent Res, 2009. 88(7): p. 627-32.

33. Labrecque, J., et al., Effects of a high-molecular-weight cranberry fraction on growth, biofilm formation and adherence of Porphyromonas gingivalis. $\mathrm{J}$ Antimicrob Chemother, 2006. 58(2): p. 439-43.

34. La, V.D., A.B. Howell, and D. Grenier, Anti-Porphyromonas gingivalis and antiinflammatory activities of A-type cranberry proanthocyanidins. Antimicrob Agents Chemother, 2010. 54(5): p. 1778-84.

35. Bodet, C., et al., Inhibition of periodontopathogen-derived proteolytic enzymes by a high-molecular-weight fraction isolated from cranberry. J Antimicrob Chemother, 2006. 57(4): p. 685-90.

36. Ofek, I., J. Goldhar, and N. Sharon, Anti-Escherichia coli adhesin activity of cranberry and blueberry juices. Adv Exp Med Biol, 1996. 408: p. 179-83.

37. Bodet, C., F. Chandad, and D. Grenier, Anti-inflammatory activity of a highmolecular-weight cranberry fraction on macrophages stimulated by lipopolysaccharides from periodontopathogens. J Dent Res, 2006. 85(3): p. 2359. 
38. Jann, K., et al., [Immunochemical studies of $K$ antigens from Escherichia coli. II. $K$ antigen from E. coli 08:K42(A): H-]. Biochem Z, 1965. 342(1): p. 1-22.

39. Obayashi, T., et al., [Development of a new chromogenic Limulus test specific to endotoxin]. Rinsho Byori, 1985. 33(6): p. 639-44.

40. Obayashi, T., et al., A new chromogenic endotoxin-specific assay using recombined limulus coagulation enzymes and its clinical applications. Clin Chim Acta, 1985. 149(1): p. 55-65.

41. Hou, L.T., C.M. Liu, and E.F. Rossomando, Crevicular interleukin-1 beta in moderate and severe periodontitis patients and the effect of phase I periodontal treatment. J Clin Periodontol, 1995. 22(2): p. 162-7.

42. Lima, V., et al., Effects of tumor necrosis factor-alpha inhibitors pentoxifylline and thalidomide on alveolar bone loss in short-term experimental periodontal disease in rats. J Periodontol, 2004. 75(1): p. 162-8.

43. Assuma, R., et al., IL-1 and TNF antagonists inhibit the inflammatory response and bone loss in experimental periodontitis. J Immunol, 1998. 160(1): p. 403-9.

44. Yang, F., et al., Green tea polyphenols block endotoxin-induced tumor necrosis factor-production and lethality in a murine model. J Nutr, 1998. 128(12): p. 233440 .

45. Ahuja, S., B. Kaack, and J. Roberts, Loss of fimbrial adhesion with the addition of Vaccinum macrocarpon to the growth medium of P-fimbriated Escherichia coli. J Urol, 1998. 159(2): p. 559-62.

46. Babu, J., et al., Inhibition of Streptococcus gordonii metabolic activity in biofilm by cranberry juice high-molecular-weight component. J Biomed Biotechnol, 2012. 2012: p. 590384.

47. Schumann, R.R., et al., Structure and function of lipopolysaccharide binding protein. Science, 1990. 249(4975): p. 1429-31.

48. Wright, S.D., et al., CD14, a receptor for complexes of lipopolysaccharide (LPS) and LPS binding protein. Science, 1990. 249(4975): p. 1431-3.

49. Hailman, E., et al., Lipopolysaccharide (LPS)-binding protein accelerates the binding of LPS to CD14. J Exp Med, 1994. 179(1): p. 269-77.

50. da Silva Correia, J., et al., Lipopolysaccharide is in close proximity to each of the proteins in its membrane receptor complex. transfer from CD14 to TLR4 and MD-2. J Biol Chem, 2001. 276(24): p. 21129-35. 
51. Gutteridge, J.M. and J. Mitchell, Redox imbalance in the critically ill. Br Med Bull, 1999. 55(1): p. 49-75.

52. Miller, D.M., G.R. Buettner, and S.D. Aust, Transition metals as catalysts of "autoxidation" reactions. Free Radic Biol Med, 1990. 8(1): p. 95-108.

53. Valko, M., H. Morris, and M.T. Cronin, Metals, toxicity and oxidative stress. Curr Med Chem, 2005. 12(10): p. 1161-208.

54. Decoursey, T.E. and E. Ligeti, Regulation and termination of NADPH oxidase activity. Cell Mol Life Sci, 2005. 62(19-20): p. 2173-93.

55. Halliwell, B., K. Zhao, and M. Whiteman, Nitric oxide and peroxynitrite. The ugly, the uglier and the not so good: a personal view of recent controversies. Free Radic Res, 1999. 31(6): p. 651-69.

56. Cai, J. and D.P. Jones, Superoxide in apoptosis. Mitochondrial generation triggered by cytochrome c loss. J Biol Chem, 1998. 273(19): p. 11401-4. 


\section{VITA}

Vreiti Sangha, B.D.S., D.D.S. was born in Panipat, India, in the year 1976. She received her Bachelor of Dental Surgery in 2000, from Kurukshetra University, India.

She then received her D.D.S. degree from University of Alberta, College of Dentistry in 2005 in Edmonton, Alberta, Canada.

She is currently enrolled as a graduate student in the Department of

Periodontology at The University of Tennessee Health Science Center. She will receive her degree of Master of Dental Science in May 2012. 